\title{
Acetaminophen micropollutant: Historical and current occurrences, toxicity, removal strategies and transformation pathways in different environments
}

Hoang, Nam Nhat; Ky Le, Gia; Minh Hong Nguyen, Thi; Bui, Xuan Thanh; Nguyen, Khanh Hoang; Rene, Eldon R.; Vo, Thi-Dieu-Hien; Thanh Cao, Ngoc-Dan; Mohan, Raj

\section{Published in:}

Chemosphere

Link to article, DOI:

/10.1016/j.chemosphere.2019.124391

Publication date:

2019

Document Version

Peer reviewed version

Link back to DTU Orbit

Citation $(A P A)$ :

Hoang, N. N., Ky Le, G., Minh Hong Nguyen, T., Bui, X. T., Nguyen, K. H., Rene, E. R., Vo, T-D-H., Thanh Cao, N-D., \& Mohan, R. (2019). Acetaminophen micropollutant: Historical and current occurrences, toxicity, removal strategies and transformation pathways in different environments. Chemosphere, 236, [124391]. https://doi.org//10.1016/j.chemosphere.2019.124391

\section{General rights}

Copyright and moral rights for the publications made accessible in the public portal are retained by the authors and/or other copyright owners and it is a condition of accessing publications that users recognise and abide by the legal requirements associated with these rights.

- Users may download and print one copy of any publication from the public portal for the purpose of private study or research.

- You may not further distribute the material or use it for any profit-making activity or commercial gain

- You may freely distribute the URL identifying the publication in the public portal 


\section{Accepted Manuscript}

Acetaminophen micropollutant: Historical and current occurrences, toxicity, removal strategies and transformation pathways in different environments

Hoang Nhat Phong Vo, Gia Ky Le, Thi Minh Hong Nguyen, Xuan-Thanh Bui,

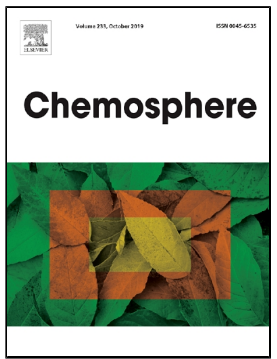

Khanh Hoang Nguyen, Eldon R. Rene, Thi-Dieu-Hien Vo, Ngoc-Dan Thanh Cao, Raj Mohan

PII:

S0045-6535(19)31612-1

DOI:

10.1016/j.chemosphere.2019.124391

Article Number:

124391

Reference:

CHEM 124391

To appear in:

Chemosphere

Received Date:

14 April 2019

Accepted Date:

16 July 2019

Please cite this article as: Hoang Nhat Phong Vo, Gia Ky Le, Thi Minh Hong Nguyen, Xuan-Thanh Bui, Khanh Hoang Nguyen, Eldon R. Rene, Thi-Dieu-Hien Vo, Ngoc-Dan Thanh Cao, Raj Mohan, Acetaminophen micropollutant: Historical and current occurrences, toxicity, removal strategies and transformation pathways in different environments, Chemosphere (2019), doi: 10.1016/j.

chemosphere.2019.124391

This is a PDF file of an unedited manuscript that has been accepted for publication. As a service to our customers we are providing this early version of the manuscript. The manuscript will undergo copyediting, typesetting, and review of the resulting proof before it is published in its final form. Please note that during the production process errors may be discovered which could affect the content, and all legal disclaimers that apply to the journal pertain. 
1 Acetaminophen micropollutant: Historical and current occurrences, toxicity, removal

2 strategies and transformation pathways in different environments

3 Hoang Nhat Phong Vo ${ }^{1}$, Gia Ky Le ${ }^{2}$, Thi Minh Hong Nguyen ${ }^{2}$, Xuan-Thanh Bui ${ }^{3{ }^{3},}$, Khanh Hoang

4 Nguyen ${ }^{4}$, Eldon R. Rene ${ }^{5}$, Thi-Dieu-Hien $\mathrm{Vo}^{6, *}$, Ngoc-Dan Thanh $\mathrm{Cao}^{6}$, Raj Mohan ${ }^{7}$

5

$6 \quad{ }^{1}$ Institute of Research and Development, Duy Tan University, Da Nang, Viet Nam.

$7 \quad{ }^{2}$ Environmental Engineering and Management Program, Asian Institute of Technology (AIT), P.O. Box

8 4, Klong Luang, Pathumthani 12120, Thailand.

$9 \quad{ }^{3}$ Faculty of Environment and Natural Resources, Ho Chi Minh City University of Technology, VNU10 HCM, Viet Nam.

$11{ }^{4}$ National Food Institute, Denmark Technical University, 2800 Kgs. Lyngby, Denmark.

$12{ }^{5}$ Department of Environmental Engineering and Water Technology, IHE - Delft, Institute of Water 13 Education 2601 DA, Delft, the Netherlands.

${ }^{6}$ NTT Institute of Hi-Technology, Nguyen Tat Thanh University, Ho Chi Minh City, Viet Nam.

${ }^{7}$ National Institute of Technology Karnataka, Surathkal, Karnataka, Dakshina Kannada - 575025, India.

*Corresponding author: 


\section{Abstract}

23

Acetaminophen (ACT) is commonly used as a counter painkiller and nowadays, it is increasingly present in the natural water environment. Although its concentrations are usually at the ppt to ppm levels, ACT can transform into various intermediates depending on the environmental conditions. Due to the complexity of the ACT degradation products and the intermediates, it poses a major challenge for monitoring, detection and to propose adequate treatment technologies. The main objectives of this review study were to assess (i) the occurrences and toxicities, (2) the removal technologies and (3) the transformation pathways and intermediates of ACT in four environmental compartments namely wastewater, surface water, ground water, and soil/sediments. Based on the review, it was observed that the ACT concentrations in wastewater can reach upto several hundreds of ppb. Amongst the different countries, China and the USA showed the highest ACT concentration in wastewater $(\leq 300$ $\mu \mathrm{g} / \mathrm{L})$, with a very high detection frequency (81-100\%). Concerning surface water, the ACT concentrations were found to be at the ppt level. Some regions in France, Spain, Germany, Korea, USA, and UK comply with the recommended ACT concentration for drinking water (71 ng/L). Notably, ACT can transform and degrade into various metabolites such as aromatic derivatives or organic acids. Some of them (e.g., hydroquinone and benzoquinone) are toxic to human and other life forms. Thus, in water and wastewater treatment plants, tertiary treatment systems such as advanced oxidation, membrane separation, and hybrid processes should be used to remove the toxic metabolites of ACT.

\section{Keywords}

Micropollutant, acetaminophen, pharmaceutical and personal care products, intermediates, wastewater treatment 


\section{Introduction}

In recent years, acetaminophen (ACT) is one of the most consumed pharmaceutical and personal care products (PPCPs) in many countries. For instance, in 2009, 54.3 and $22.6 \mathrm{~g}$ ACT/inhabitant per year was reported in France and Spain, respectively (Ortiz de García et al., 2013). Likewise, the Taiwan citizens used $~ 580$ million ACT doses in 2004 (Lin and Tsai, 2009). After consumption, ACT is excreted in both native and metabolized forms to the sewer systems, wastewater treatment plants (WWTPs) and other aquatic/natural environments. ACT in wastewater has been detected frequently in various countries from Asia, Europe and Americas. It inflicts significant negative impacts to the aquatic and ecological systems. Additionally, through drinking water and food consumption, it can enter the human body and cause significant health effects (Baron et al., 2014). The long-term exposure would result in cancer, endocrine disruption, antibiotic-resistant and several chronic diseases (Fisher and Curry, 2019). Therefore, the proper removal of ACT and its metabolites/degradation products from water, prior to being discharged to the environment, is important in order to preserve the environmental quality.

For the removal of ACT from water, numerous treatment technologies have been developed and tested both at the laboratory and pilot scales. These include biological processes, advanced oxidation processes (AOP), constructed wetlands (CWs), adsorption and membrane processes. Evidently, the principles and working mechanisms of these technologies are different and they remove $\mathrm{ACT}$ at different efficiencies depending on the concentration of $\mathrm{ACT}$, its source, geographical and environmental conditions. For example, biological processes are green and safe, but high concentrations of ACT can inhibit the microbial activity. In turn, AOPs are rather fast and efficient for high concentrations of ACT; however, AOPs consume more chemicals and they are energy intensive. The degradation mechanism is also different for a biological process and a AOP. For instance, in the case of AOPs, the hydroxyl radicals $\left({ }^{\circ} \mathrm{OH}\right)$, in the 
presence of photon energy would create chemical breakdown of the ACT molecules and transform them into different ACT metabolites. In a biological process, the microorganisms or the biocatalyst degrade/mineralize the ACT by enzyme mediated biochemical reactions the and convert ACT into metabolites. Consequently, the different treatment technologies should be differentiated clearly and selected depending on the level of treatment required.

After degradation by the different treatment technologies, intermediates/by products are formed which entail another issue of secondary ACT pollution. The transformation pathway, and the metabolites of ACT occur synergistically in wastewater treatment systems and other aquatic environments. In essence, several transformation processes have been proposed and more than 20 by-products have been identified during the past 15 years (Andreozzi et al., 2003; de Luna et al., 2013). However, these metabolites pose different toxicities. Some of them are more detrimental than the parent forms such as $N$-acetyl-p-benzoquinone imine (Liang et al., 2016). From a health viewpoint, such aromatic intermediates can result in failure of liver functions in humans (Fisher and Curry, 2019). Hence, the transformation pathways and byproducts of ACT should be identified and studied systematically.

From all the above concerns, this review study aims to assess the following aspects: (i) the occurrences and toxicities, (ii) the different treatment/removal technologies, and (iii) the transformation pathways and intermediates of ACT in four environmental compartments (i.e. wastewater, surface water, ground water, and soil/sediments). By clarifying such stated issues, this review delineates and proposes a sustainable management and treatment option for ACT pollution.

\section{Occurrences of acetaminophen in various environments}

Human wastes, domestic and industrial wastewater are the major sources of ACT, a persistent micropollutant in the natural environment. Various household activities dispose ACT to the sewage systems and ACT is collected in the WWTPs. After the treatment process(es) in 
WWTPs, ACT still remains in the effluent and is released to water reservoirs and contaminates soil, sediment and groundwater. Thus, ACT occurs mainly in four environments: sewage and WWTPs, surface water, groundwater and soil and sediments.

\subsection{Sewage and wastewater treatment plants}

In 1998, a number of WWTPs in Germany were examined if the treatment systems contained ACT; however, surprisingly, it was not detected (Ternes, 1998). Although it could one isolated finding, ACT has been detected across continents, at varying concentrations and detection frequencies (Fig. 1). In 2006, ACT in wastewater was investigated in South Korea, China, United States of America (USA), France, United Kingdom (UK) and many other countries worldwide. The concentration of ACT ranged from 0.1 to $300 \mu \mathrm{g} / 1$ and its detection frequency reached up to $100 \%$.

In Asia, several countries reported their wastewater being contaminated by ACT such as South Korea, China and Taiwan. From Fig. 1, it is evident that the documented sites were mostly in mega cities and their nearby regions (e.g., Busan, Ulsan and Xiamen) with high-density population. In the case of South Korea, ACT accounted for $18-80 \%$ of the total PPCPs in wastewater in the year 2007 (Kim et al., 2007a; Sim et al., 2010). From the year 2008 to 2012, ACT concentration in sewages and WWTPs increased by $\sim 11$-fold from 6.8 to $75 \mu \mathrm{g} / 1$ (Sim et al., 2010; Kim et al., 2012). The main reason was attributed to the high ACT consumption rate in South Korea. In the year 2004, Korean consumed 9 tons ACT and the ACT consumption rate only started to rise from 2008 to 2012 (Sim et al., 2010). Similarly, in China, the ACT concentration was recorded at $3.4 \mu \mathrm{g} / \mathrm{l}$ in sewages and WWTPs and it was ranked as the highest amongst all the assessed PPCPs (Sun et al., 2016b). Therefore, researchers suggested ACT as the marker for PPCPs pollution in China. In comparison with the Korean survey, the Chinese citizens also used ACT widely and the survey showed values ranging from $10-18 \mathrm{~g} / \mathrm{d}$ per 1000 inhabitants (Gao et al., 2016). In Taiwan, ACT was the most detected compound in WWTPs 
effluent because the Taiwanese citizens have consumed 579 million doses of ACT (different forms) in 2004 (Lin and Tsai, 2009). This was 4 times higher than the propanolol dose of 156 millions, being the second most-consumed PPCPs.

In Europe, the pattern of ACT contamination differed from those observed in Asia. Countries such as Greece and France showed 100\% ACT detection frequency in WWTPs (Gros et al., 2010; Papageorgiou et al., 2016). Although its detection frequencies were higher than in Asia, nevertheless, the total amount of ACT accounted for only $1-2 \%$ of the total PPCPs in wastewater compared with $18-80 \%$ in Asia (Rabiet et al., 2006). These values can be considered to be acceptable because European citizens used $320 \mathrm{mg} / \mathrm{d}$ per 1000 inhabitants, much less than the values of $10-18 \mathrm{~g} / \mathrm{d}$ per 1000 inhabitants of the Asian region (Kosma et al., 2010).

Concerning the United States, the ACT concentration in WWTPs was more pronounced than other countries. For example, in the year 2006, $0.96 \mu \mathrm{g}$ ACT/L was reported in Baltimore, and these values subsequently increased 100-fold $\mu \mathrm{g} / 1$ after 2012 (Hedgespeth et al., 2012; Blair et al., 2013; Kosma et al., 2014). Besides, in the United States, ACT accounted for $~ 45 \%$ of the total PPCPs present in the hospital effluent (Oliveira et al., 2015). Its concentration was $\sim 220 \mu \mathrm{g} / \mathrm{l}$ and the highest values were observed during the winter season due to the pattern of consumption ( $\mathrm{Yu}$ et al., 2013). ACT is being used in hospitals; thus, its concentration in wastewater was 3-fold higher than those observed normally in municipal WWTPs. In the case of Colombia, ACT concentration in sewage and WWTPs varied from 9.2 to $39.2 \mu \mathrm{g} / 1$ (BoteroCoy et al., 2018), which is nearly similar to the amounts reported in WWTPs samples from the Asian region.

During 8 years, from 1998 to 2006, ACT was detected increasingly in many countries and regions. Since the invention of ACT in 1955 for medication purposes, ACT was consumed even more. Although it was not detected in German WWTPs in the year 1998, it might be 
possible that the ACT concentration was below the detection limit in that study. In the following years, modern analytical techniques, tools and technologies are well-developed and these instruments can detect even low concentrations. Additionally, micropollutants have attracted a growing interest amongst researchers from various disciplines, ranging from public health, engineering, geochemistry to policy and governance.

[Insert Fig. 1]

\subsection{Surface water}

In developing countries, industrial effluent, municipal wastewater, hospital wastewater and septic tank effluent are often not collected and treated properly. This causes the wide spread prevalence of ACT in surface water. Unlike in the case of sewage and WWTPs, the concentration of ACT in surface water reduced chronologically with respect to the years. At the early stage, ACT was detected in surface water at the ppb concentration levels $(10 \mu \mathrm{g} / \mathrm{l}$ in 2002) (Kolpin et al., 2002). In recent reports, the concentration of ACT decreased to ppt levels (Lv et al., 2014; You et al., 2015; Lin et al., 2016c).

Similar to sewage and WWTPs, ACT was detected in surface water of several Asian countries such as South Korea, China, Taiwan and Singapore. In South Korea, ACT was present in many rivers with the highest occurrence frequency $(80 \%)$ and concentration $(33 \mathrm{ng} / \mathrm{l})$ than other PPCPs (Kim et al., 2007a). For example, they existed in the three biggest rivers in South Korea: Han, Nakdong and Youngsan, respectively. Particularly, they were present in 9/12 of the water samples collected from rivers (Choi et al., 2008); 6/8 of the water samples collected from wastewater treatment plants and surface waters (Kim et al., 2007a), and 2/5 of the river water samples (Sim et al., 2010). In China, ACT concentration in surface water was comparable to the values reported from South Korea. Specifically, ACT existed in the range of 9.8 to $197 \mathrm{ng} / \mathrm{l}$ in Taihu lake and Jiulong river, while other PPCP concentrations were found to be below the detection limit (Lv et al., 2014; Lin et al., 2016c; Sun et al., 2016b). In Taiwan and Singapore, 
170

171

172

173

174

175

176

177

178

179

180

181

182

183

184

185

186

187

188

189

190

191

192

193

194

ACT was dominant (33 - 95\%) among the total PPCPs in surface waters (Lin and Tsai, 2009;

You et al., 2015). Incidentally, these water reservoirs received discharges from various industrial activities and supplied drinking water to the local communities in the region.

Concerning Europe, in France and Spain, the ACT detection frequency in surface water was in the range of $28-41 \%$ (Vulliet and Cren-Olivé, 2011; Vazquez-Roig et al., 2012) and its concentration varied from 0.4 to $71 \mathrm{ng} / \mathrm{l}$. However, the studied (sampled) regions were remote areas like national parks and mountain lakes. Elsewhere, the Ensanche region of Northwest Spain recorded a maximum ACT concentraton of $5.71 \mu \mathrm{g} / 1$ (wet weather) and $0.72 \mu \mathrm{g} / 1$ (dry weather), respectively (Del Río et al., 2013). This area was used as a catchment for wastewater discharge by the local communities.

In United States, the ACT concentration and detection frequency in Michigan lake was 2.5 $17 \mathrm{ng} / \mathrm{l}$ and 25\%, respectively (Ferguson et al., 2013). Michigan lake was the catchment serving drinking water for a larger part of the community in the region. It also received wastewater from the local communities. Thus, ACT concentration in these densely populated areas overtook the open water/catchment sites. In the Mississippi river, ACT concentration ranged from 24.7 - $65.2 \mathrm{ng} / \mathrm{L}$, which was higher than the values reported from Michigan lake (Zhang et al., 2007). The Mississippi river carried $\sim 66 \%$ suspended solids (SS) from the mainland of the United States to the ocean. Interestingly, the presence of suspended solids adsorbed and reduced a significant amount of ACT and other PPCPs present in the river water. Previously, Boyd et al. (2003) tested water samples collected from the Mississippi river and Pontchartrain lake and reported that ACP were below the detectable levels.

In general, ACT detection frequencies $(<50 \%)$ and ACT concentrations in surface waters of Europe and America was less than those reported in Asia. In surface water, ACT concentration is usually influenced by several environmental, geographical and social factors. The most important parameter was, however, the polulation - given that Europe and United States has 
195

196

197

198

199

200

201

202

203

204

205

206

207

208

209

210

211

212

213

214

215

216

217

218

219

less population density compared to Asia. Geographical condition such as rainfall also affected the ACT concentration in surface water. For example, according to a field study, Michigan lake received runoff and rainfall that diluted the ACT concentration several fold after the monsoon season (Ferguson et al., 2013). Neverhtless, from the yearly trends, it is evident that the ACT concentration in surface water has reduced in recent years. Such drop in the ACT levels can be attributed to the better performance of WWTPs, innovations in research, awareness and enactment of policies and regulations. Besides, the discharge standards for micropollutant have been gradually been established in many countries. In 2008, the United States Environmental Protection Agency (USEPA) developed a "White Paper Aquatic Life Criteria for Contaminants of Emerging Concern: Part I Challenges and Recommendations" and, in the meantime, Directive 2000/60/EC and 2008/105/EC were published by the European Commission. In Asia, discharge standards for micropollutants is still scarce or they are still at the policy approval level. Some of the new treatment technologies and discharge standards have compromised ACT concentration $<71 \mathrm{ng} / 1$ that makes the water suitable for drinking purposes (Vulliet and Cren-Olivé, 2011). However, in the case of European countries, although the levels of ACT were reported to be high in some reports, the policies and guidelines are substantially stronger and well-implemented than in many Asian countries.

\subsection{Groundwater}

The sources of ACT pollution in ground water are similar to those observed in surface water, industrial effluent, municipal WWTP, septic tank and landfill. The leakage of septic tank and landfill can contain concentrated pollutants in the range of $100-1000 \mathrm{ng} / \mathrm{l}$ of ACT (Lapworth et al., 2012). ACT contaminated ground water has been reported in many countries and regions. In France and Serbia, ACT appeared in $17 \%$ and $15 \%$ of the groundwater samples tested (Grujić et al., 2009; Vulliet and Cren-Olivé, 2011). In the Tennessee River basin (USA), ACT concentration was in the range of $2.1-12.3 \mathrm{ng} / \mathrm{l}$ and it was present in $\sim 13 \%$ of the groundwater 
220

221

222

223

225

226

227

228

229

230

231

232

233

234

235

236

237

238

239

240

241

242

243

samples (Conley et al., 2008). In California, the ACT detection frequency and maximum concentration were $0.32 \%$ and $1.89 \mu \mathrm{g} / \mathrm{l}$, respectively (Fram and Belitz, 2011). Thus, ground water is less contaminated than wastewater and surface water because the ACT containing stream is usually filtered by the soil layers as it penetrates gradually into the soil layers (He et al., 2016). Nevertheless, studies related to the identification/quantification of ACT in ground water is scarce compared to wastewater and surface water. Hence, the available reports related to ground water contamination due to ACT might not reflect the actual problem adequately. In developing countries, septic tanks are used widely but their quality and durability still remains a challenge and persisting problem. Anew, the management policies concerning landfills in Asia is rather poorly defined and incomplete. Those must be considered for micropollutant control in the future.

\subsection{Sediment and soil}

Similar to drinking water, ACT has also contaminated the soil and sediment environments, e.g. the Pego-Oliva marsh in Spain. ACT was detected in $87 \%$ of the soil and $91 \%$ of the sediment samples with maximum concentrations of $15.1 \mathrm{ng} / \mathrm{l}$ and $1.8 \mathrm{ng} / \mathrm{g}$, respectively (Vazquez-Roig et al., 2012). Notably, ACT settles and accumulates in sediment and soil faster than in surface water. In samples collected from the Masan Bay in South Korea, ACT was an indicator of micropollutant pollution. It was detected in $>50 \%$ of the sediment samples with a concentration of $2.2 \mathrm{ng} / \mathrm{g}$ sediment (Choi et al., 2014). The Masan Bay was one of the most polluted coastal area in South Korea due to effluent discharges from heavy industries and highly urbanized cities. According to the authors, the ACT detection frequencies in soil and sediment were high because ACT could adsorb onto the solid phase and settle easily than in surface waters. Although its concentration in sediment and soil still remained at the ppt level, it could increase gradually in the next coming years due to (bio)accumulation and (bio)magnification. 
The salient observations can be summarized as follows: (i) ACT concentration in wastewater is constantly increasing since 1998 to the present values of several $100 \mathrm{ppb}$; (ii) in surface water, ACT concentration decreased to ppt from the same time but has contaminated the larger surface areas, (iii) groundwater is less polluted with ACT than surface water, and (iv) soil and sediment environments accumulated ACT from surface water. These evidences clearly illustrate that ACT can be an indicator for the presence of micropollutants in several countries. Although the pattern of ACT contamination in those countries were different, China and the USA showed the highest ACT detection frequency ranging from $81-100 \%$, compared to 22 $73 \%$ in France, Spain and Singapore. In some reports from United States, UK, Colombia and Taiwan, ACT concentrations were $>300 \mu \mathrm{g} / \mathrm{l}$. France recorded the lowest ACT detection frequency $(<39 \%)$ and concentration $<0.1 \mu \mathrm{g} / \mathrm{l}$. Table 1 classifies the countries depending on their levels of ACT contamination.

\section{[Insert Table 1]}

\section{Toxicities of acetaminophen}

ACT is toxic to both aquatic and human life. It causes genetic code damage, oxidative degradation of lipids and denaturation of protein in cells. The toxicity of ACT can vary from low to moderate depending on acute and chronic exposure conditions (Kosma et al., 2010). The effective concentration $\left(\mathrm{EC}_{50}\right)$ and exposure time to $\mathrm{ACT}$ are summarized in Table 2.

\section{[Insert Table 2]}

The toxicity of ACT has been studied in several hosts such as bacteria, algae, macrophytes, protozoan and fish. Amongst those, the freshwater invertebrate and cell in-vitro showed the lowest effective concentration, i.e. $<50 \mathrm{mg} / \mathrm{l}$ (Henschel et al., 1997; Kim et al., 2007b). This implies that these species were sensitive to ACT. In turn, bacteria and macrophyte species were recalcitrant to ACT. Most of the authors have reported that their $\mathrm{EC}_{50}$ values were $>400 \mathrm{mg} / \mathrm{l}$ (Henschel et al., 1997; Kim et al., 2007b). 
269

270

ACT can be present in drinking water and it would endanger public health. However, the risk assessment method of PPCPs in drinking water has not been established officially. Instead, two main procedures have been proposed in the literature, i.e. the measured and predicted concentrations. For instance, Vulliet and Cren-Olivé (2011) followed this approach to estimate the maximum levels of ACT in drinking water. The maximum value for drinking water was reported as $71 \mathrm{ng} / \mathrm{l}$ and the daily ACT intake was $142 \mathrm{ng} / \mathrm{l}$. The ACT concentrations of some surface water sources have reported to be $>71 \mathrm{ng} / \mathrm{l}$, such as the Hérault River Basin of France River Taff and River Ely of the UK, Sindian and Dahan river of Taiwan, Jiulong River of China and many areas of the United States (Rabiet et al., 2006; Kasprzyk-Hordern et al., 2008; Lin and Tsai, 2009; Lv et al., 2014).

\section{Removal technologies for acetaminophen (ACT)}

Several technologies have been developed, both at the laboratory and field scale, for the removal of micropollutants. They range from biological, physical, chemical to hybrid and advanced technologies. The common technologies for ACT removal including biological processes, AOPs, plant uptake, adsorption, membrane processes, hybrid processes and other technologies were reviewed and discussed. In essence, they differ from originalities and mechanisms. For example, the AOPs are regulated by chemical reactions and physical processes, e.g, Fenton's reagent/photo-Fenton process. The adsorption and membrane processes are largely physical treatments, while plant uptake (phytoremediation), activated sludge process and anaerobic process refer to biological treatment.

\subsection{Biological processes}

Biological processes refer to the removal of micropollutants using suitable biocatalysts under aerobic or anaerobic environments. The pollutant removal mechanisms of biological processes comprise of biosorption, biodegradation and bioaccumulation. In practice, the commonly used biological processes include the activated sludge process, anaerobic process, microalgae based 
294

295

296

297

photobioreactor and microalgae based pond system. However, during wastewater treatment, these technologies yield different advantages and limitations for ACT removal.

Activated sludge process has proven to be effective for the removal of ACT from wastewater. For example, in the Baltimore WWTP (USA), it could remove 99\% ACT in $14 \mathrm{~d}$ (Yu et al., 2006). A half of ACT dose was biotransformed within $4 \mathrm{~d}$. In the Coslech WWTP (UK), an activated sludge process eliminated 100\% ACT from wastewater (Kasprzyk-Hordern et al., 2009). Although ACT was removed efficiently in the system, according to the authors, it was not mineralized completely and bioaccumulation, physical adsorption and biodegradation contributed to $>99 \%$ removal efficiency. After treatment, the wasted sludge can be composted, incinerated or treated in an anaerobic digester.

Similar to an activated sludge process, anaerobic systems could also remove $>75 \%$ ACT from wastewater. According to a recent study, ACT was retained in the anaerobic sludge biomass to a value of $35 \mathrm{~g} / \mathrm{kg}$ (Narumiya et al., 2013). The superiority of anaerobic process(es) compared to a conventional anaerobic process is that this process could tolerate high dose of ACT, ranging from 50 to $1000 \mathrm{mg} / \mathrm{l}$. Over this dose, ACT would inhibit the anaerobic microbial community in the reactor (Alvarino et al., 2014). In addition, ACT concentrations $>250 \mathrm{mg} / 1$ could hamper/inhibit the nitrification and denitrification rates.

Regarding microalgae, a high rate algae pond could handle wastewater containing $9 \mu \mathrm{g}$ ACT/1 from 4 to $8 \mathrm{~d}$ (Matamoros et al., 2015). When compared to the microorganisms present in the activated sludge process and the anaerobic process, microalgae are less tolerant to ACT stress. The effective ACT concentration causing toxicity to algae ranges from 134 - $240 \mathrm{mg} / \mathrm{l}$; whereas the inhibitory concentration for certain bacteria ranged between 550 and $650 \mathrm{mg} / \mathrm{l}$ (Table 2). Hence, in order to enhance the overall removal efficiency, algal cells were immobilized to intert matrices such as sponge, bead and nanoparticles. As a result, the immobilized algal cells were 
able to tolerate ACT, achieving $100 \%$ efficiency at a concentration of $100 \mu \mathrm{g} / \mathrm{l}$ in $8 \mathrm{~d}(\mathrm{Yu}$ et al., 2011).

From these previous reports, it is clearly evident that biological processes could treat wastewater containing high levels of ACT, upto hundreds of ppb. From a practical viewpoint, in WWTPs, biological processes are prone to receive fluctuating concentrations/loading rates of wastewater. In order to withstand the shock load effects on the biological system, the application of an equalization tank will help to maintain the ACT concentrations at values $<50$ $\mathrm{mg} / \mathrm{l}$ for anaerobic treatment and $500 \mu \mathrm{g} / \mathrm{L}$ for aerobic treatment, respectively. Algal pond systems can still be considered as a post-treatment step because it can easily tolerate low ACT concentrations present in wastewater. However, some of these biological processes require long start-up or acclimation time, high surface (land) area, long solids and hydraulic retention time and the removal efficiency depends on the composition and concentration of pollutant(s) present in the wastewater. Nevertheless, complete mineralization of the ACT is still not accomplished in biological treatment systems, thus, a tertiary treatment step as AOPs, plant uptake, adsorption and/or membrane processes are usually required. The tertiary treatment step could also be used as a pre-treatment step to reduce the load of wastewater to the biological process, thereby reducing the size of bioreactors and completely eliminate ACT from the treated effluent.

\subsection{Plant uptake processes}

Plant can uptake organics, inorganics and a wide variety of recalitrant pollutants present in wastewater (Vo et al., 2018). Thus, it can also be considered as an option for ACT removal. In natural/constructed wetlands, the plants uptake ACT via the root, and its accumulated and thereafter translocated. In addition, the plant rhizosphere offers co-benefits for other removal processes, by promoting microbial growth in the wetland and alleviating clogging of the media bed. Although plant contributes greatly to the removal of ACT, depending on the plant species, 
the removal efficiency could vary largely. For instance, $P$. australis removed $\sim 51-99 \%$ ACT from contaminated water, while T. latifolia reduced 46.7 - 99.9\% ACT (Ranieri et al., 2011). Some plant species could also contribute to the transformation of ACT (Huber et al., 2009; Wu et al., 2013).

The fate and metabolism of ACT was investigated in the tissues of Armoracia rusticana (Huber et al., 2009). After $6 \mathrm{~h}$ of incubating the plant species in ACT containing wastewater, ACT and its metabolites were detected in the plant tissues. The metabolites consisted of $18 \%$ ACT, $64 \%$ paracetamol glucoside, $17 \%$ paracetamol glutathione and $1 \%$ cysteine conjugate, respectively. However, after $168 \mathrm{~h}, 88 \%$ ACT in the plant root system had reduced and transformed to other metabolities. Similarly, Brassica juncea was able to uptake $22 \%$ ACT within $3 \mathrm{~d}$. The authors confirmed that the shoot was responsible for determining the fate of ACT transformation and its metabolites (Bartha et al., 2010). The conjugation of ACT - glutathione and glucose occurred in the plant tissues and these mechanisms are somewhat similar to those occurring in mammals. The transformation process of ACT in plant tissues depends on the plant species, lasting from $6 \mathrm{~h}$ to $3 \mathrm{~d}$. Using plants, wastewater containing ACT $<5 \mu \mathrm{g} / \mathrm{l}$ can be handled effectively and this technique can be used as a post-treatment step to reduce ACT to ppt levels.

\subsection{Advanced oxidation processes}

\subsubsection{Chemical-based Fenton processes}

Chemical-based Fenton reaction is one of the commonly reported AOP. The chemical-based Fenton includes classical Fenton, Fenton-like and bio-Fenton processes. It produces hydroxyl radical groups that plays a major role in the degradation/mineralization of ACT (Eq. 1 \& 2):

$$
\begin{aligned}
& \mathrm{Fe}^{2+}+\mathrm{H}_{2} \mathrm{O}_{2} \rightarrow \mathrm{Fe}^{3+}+\mathrm{HO}^{-}+{ }^{\cdot} \mathrm{OH} \\
& \mathrm{Fe}^{3+}+\mathrm{H}_{2} \mathrm{O}_{2} \rightarrow \mathrm{Fe}^{2+}+\mathrm{HO}_{2}+\mathrm{H}^{+}
\end{aligned}
$$

The ACT removal efficiency of chemical-based Fenton process is affected by the $\mathrm{pH}, \mathrm{H}_{2} \mathrm{O}_{2}$ and $\mathrm{Fe}^{2+}$ concentrations. The importance of those parameters varies in the order: $\mathrm{Fe}^{2+}>\mathrm{H}_{2} \mathrm{O}_{2}>$ 
pH (Su et al., 2012). The increase of $\mathrm{Fe}^{2+}$ and $\mathrm{H}_{2} \mathrm{O}_{2}$ concentration can enhance the ACT removal efficiency, whereas the prevailing $\mathrm{pH}$ conditions can also synergistically or antagonistically affect the ACT removal. At higher $\mathrm{pH}$ conditions, $\mathrm{Fe}^{3+}$ precipitates to amorphous $\mathrm{Fe}(\mathrm{OH})_{3}$ and reduces the regeneration of $\mathrm{Fe}^{2+}$. In a recent study, the optimal conditions were reported to be: $\mathrm{pH}-3.0, \mathrm{H}_{2} \mathrm{O}_{2}-25 \mathrm{mM}$ and $\mathrm{Fe}^{2+}-0.1 \mathrm{mM}$, to remove $5 \mathrm{mM}$ of ACT from contaminated water (Su et al., 2013a). The amorphous form of iron present in sludge damages the equipments in WWTPs. The type of iron sources used in the chemical based Fenton process is also important in the Fenton reaction. For example, artificial ferrous iron removes ACT 5\% higher than the iron source present in laterite soil (Basavaraju et al., 2011).

Referring to the mechanism, Fenton reaction degrades ACT in 2 stages including an initially occuring reaction at higher rates, followed by a reaction at slower rates (de Luna et al., 2013). In the first stage, $\mathrm{Fe}^{2+} / \mathrm{H}_{2} \mathrm{O}_{2}$ reaction occurs within 30 s to generate large amount of ${ }^{\circ} \mathrm{OH}$, while the second stage of $\mathrm{Fe}^{3+} / \mathrm{H}_{2} \mathrm{O}_{2}$ occurs after 30 s in which the $\mathrm{Fe}^{3+}$ combines with $\mathrm{H}_{2} \mathrm{O}_{2}$ to degrade ACT. Depending on the degree of treatment required, the reactioin time of a Fenton's process could be optimized.

The chemical-based Fenton's reaction has been performed in different reactors such as an aerated reactor, fluidized-bed reactor and wetlands. In an aerated reactor, it removed $99 \%$ ACT at an initial concentration of $5 \mathrm{mM}$ (Su et al., 2012). In a fluidized-bed reactor, $99.6 \% \mathrm{ACT}$ removal was observed at an initial concentration of $5 \mathrm{mM}$, within $40 \mathrm{~min}$ (de Luna et al., 2013). Bio-Fenton's process has also emerged as a novel technology as it uses the iron present in laterite soil environments and $\mathrm{H}_{2} \mathrm{O}_{2}$ from the plant rhizosphere of a constructed wetland (Phong et al., 2016). The $\mathrm{H}_{2} \mathrm{O}_{2}$ of the root tissue and iron species of laterite soil activated bio-Fenton reaction and degraded $99.5 \%$ of $\mathrm{ACT}$ at a concentration of $100 \mu \mathrm{g} / \mathrm{l}$. 
392

393

394

395

396

397

398

399

400

401

402

403

404

405

406

407

408

409

410

411

412

413

414

415

The chemical-based Fenton's reaction is almost instantaneous and highly efficient for ACT removal. The ACT removal efficiency of a chemical-based Fenton's process is typically $>75 \%$

(Table 3). As seen from Table 3, depending on the degree of treatment required, the retention times have been varied from 40 to $120 \mathrm{~min}$ in order to remove high concentrations of ACT (10 $\mathrm{mg} / \mathrm{l})$ at $\mathrm{pH}$ 3.0. Besides, a wide range of $\left[\mathrm{Fe}^{2+}\right]:\left[\mathrm{H}_{2} \mathrm{O}_{2}\right]$ ratios has been reported in the literatures, varying from 1:40 to 1:250.

[Insert Table 3]

\subsubsection{Photo-based Fenton processes}

The conventional Fenton's reaction can be modified as the photo-based Fenton's process when coupled to a light source. The photo-based Fenton's process degrades ACT 2-fold faster than the traditional Fenton's reaction (Manu and Mahamood, 2011). The photo-based Fenton's process encompasses both photolysis and photocatalytic oxidation. Commonly, the photo Fenton's reaction uses a light source such as as monochromatic UV, metal halide and xenon lamp. The light emitting diode (LED) with polychromatic function is commercially available and it is more advantageous than traditional UV lamps. $\mathrm{TiO}_{2}$-based and carbon-based materials are the preferred photocatalysts used in this process.

The photo Fenton's process removes ACT depending on the wavelength of the incident UV light source. The shorter wavelenghts offer higher energy to create the required ${ }^{\circ} \mathrm{OH}$ radicals and degrades ACT more efficiently. For example, Kim and Tanaka (2009) tested two UV systems encompassing a UV/lamp 1 (254 nm) and a UV/lamp 2 (254 nm and $185 \mathrm{~nm})$. According to the authors, the UV/lamp 1 degraded 20\% ACT and UV/lamp 2 removed 40\% ACT, respectively. Similarly, UVA of wavelength $360 \mathrm{~nm}$ removed $99 \%$ ACT at an initial concentration of $5 \mathrm{mM}$ within $40 \mathrm{~min}$ (Su et al., 2013b). In the case of UV-LED, it provides higher light intensity compared to the traditional UV mercury lamp. Thus, it creates a stronger 
416

417

418

419

420

421

422

423

424

425

426

427

428

429

430

431

432

433

434

435

436

437

438

439

440

oxidation state and removes ACT with high efficiency (Xiong and $\mathrm{Hu}, 2012$ ). The UVA-LED, at a wavelength $365 \mathrm{~nm}$ was able to remove $200 \mathrm{ppb}$ of ACT completely within $15 \mathrm{~min}$.

The photocatalytic Fenton's process involves the use of a suitable, inert catalyst in the photo Fenton system. Catalysts would increase the amount of ${ }^{\circ} \mathrm{OH}$ group and provide sufficient surface area for the adsorption of the pollutant. Hence, it improves the ACT removal efficiency. The common catalysts used in this process are carbon-based and $\mathrm{TiO}_{2}$-based materials, such as $\mathrm{BiOCl}_{x} \mathrm{I}_{y}$ nanospheres (Wang et al., 2016b), modified reticulated vitreous carbon (Arredondo Valdez et al., 2012), nano-porous $\mathrm{TiO}_{2}$ (Xie et al., 2016) and $\mathrm{BaTiO}_{3} / \mathrm{TiO}_{2}$ (Kurniawan et al., 2018). The photocatalytic systems could remove $>95 \%$ ACT, at concentrations as high as 96 mg/l (Arredondo Valdez et al., 2012). Among the different operation parameters, $\mathrm{pH}$ is important and its optimum value depends on the type and physico-chemical properties of the catalyst used. For example, a pH of 3.5 was found to be the optimal for $\mathrm{TiO}_{2}$ catalysts (Yang et al., 2008; Zhang et al., 2008), whereas it was 7.0 for $\mathrm{BaTiO}_{3} / \mathrm{TiO}_{2}$ (Kurniawan et al., 2018), or 9.0 for $\mathrm{WO}_{3} / \mathrm{TiO}_{2} / \mathrm{SiO}_{2}$ (Yanyan et al., 2017).

For a photo-based Fenton process, proper light source and catalyst are key operational parameters that affects the performance. An UV light source is preferable than a metal halide or xenon lamp source (Table 4). Compared with these light sources, UV handles higher ACT load, with shorter exposure times. Among the UV light source, UVC wavelength was two-fold better than the conventional UVA process (Yang et al., 2008). The exposure time of an UVC process is also 4-fold lower than the UVA process. This was presumably because ACT absorbed the photon energy of UVC better than UVA. If the UV light source and catalyst dose is optimized, the ACT removal efficiency can be improved. For example, a stand-alone process without a light source requires $\sim 20-25 \mathrm{~d}$ to remove $100 \mathrm{mg} \mathrm{ACT} / 1$ (He et al., 2015), or it just could remove little doses of $3 \mu \mathrm{M}$ ACT within $30 \mathrm{~min}$ (Im et al., 2015). However, the integrated system could remove $96 \mathrm{mg} \mathrm{ACT/1}$ within a short contact time of $60 \mathrm{~min}$ (Arredondo Valdez 
et al., 2012). From a practical viewpoint, the economics of the process should be considered as

it is a rather expensive process and generates secondary pollutant such as iron containing sludge.

\subsubsection{Electro-based Fenton processes}

446 The electro-based Fenton is another modification of the conventional Fenton's process. This 447 electro-based Fenton's process uses electrodes to generate the ${ }^{\circ} \mathrm{OH}$ radicals and subsequently removes ACT from wastewater. Compared to the chemical-based and photo-based Fenton's processes, it does not produce iron oxyhydroxide sludge and the overdose of $\mathrm{H}_{2} \mathrm{O}_{2}$ is controlled.

The electrodes of the electro-based Fenton's processes act as the electron donor and acceptor for the Fenton reaction. However, the efficiency relies on the characteristics of the electrode materials. Choosing an appropriate material for the electrode is important since after prolong operation, the electrode can be deteriorated. Some typical examples of electrodes include Pt and Ti-based, porous Ti/boron-doped diamond, Pt sheet and Pt gauze. These materials have demonstrated good ACT removal efficiencies. For example, the planar and porous Ti/borondoped diamond (BDD) electrodes mineralized $100 \mathrm{mg} \mathrm{ACT/1}$ (He et al., 2015). The porous electrode was superior to the planar type because it offers high surface area and active sites for the electrochemical reaction to occur. To enhance the ACT removal efficiency, catalyst dose and a light source could also be integrated with the electro-based Fenton process. For example, system with nano-schwertmannite and nano-goethite catalysts removed $500 \mu \mathrm{g} \mathrm{ACT} / \mathrm{kg}$ of sediment, completely within $3 \mathrm{~d}$ (Yang et al., 2016). Concerning the light source, it has been reported to have a very low effect in enhancing the ACT removal efficiency (de Luna et al., of the ACT present in polluted water environments. 
465

466

467

468

469

470

471

472

473

474

475

476

477

478

479

480

481

482

483

484

485

486

487

488

489

The electro-based Fenton's process includes the MFC Fenton system, cross-flow-electro Fenton system, and the double cathode electro Fenton system, respectively. Compared with other reactor types and processes, MFC Fenton is more environmentally friendly, although it requires longer reaction times (Zhang et al., 2015). Similar to the photo-based Fenton process, the electro-based Fenton process can also remove ACT from high (ppm) concentrations to the ppt levels. The electro based Fenton process can be applied as a tertiary treatment option in WWTPs. Nevertheless, it is noteworthy to mention that the electro based Fenton process is rather expensive compared to other processes described herein, because it consumes a lot of electricity, chemicals and catalysts. Anew, periodic maintenance is required for this process since the amorphous $\mathrm{Fe}(\mathrm{OH})_{3}$ adheres to the electrodes and decreases the overall ACT removal efficiency.

\subsubsection{Ozonation}

Ozonation is an established AOP used commonly in drinking water treatment. The ozonation process and its reactions generate free radical groups of $\mathrm{O}_{3}^{-}, \mathrm{HO}_{2} \bullet$ and $\mathrm{O}_{2} \bullet$ that has high oxidation states and the spontaneous reactions mineralizes the pollutants. Ozonation has been used extensively for both surface water and wastewater treatment (Trang et al., 2014; Vo et al., 2019). For surface water, ozone dose of $5 \mathrm{mg} / \mathrm{l}$ can completely remove ACT within $30 \mathrm{~min}$ (Lutpi et al., 2015). However, the removal rates achieved in this process ( 0.7 to 45.7 per mM.s) depends on the water quality. The higher dissolved organic carbon (DOC) concentration and alkalinity increases the removal rate of ACT (Lutpi et al., 2015). In another study, wastewater containing ACT was removed at the rate of $0.2 \mathrm{mg}$ ACT/1 within $25 \mathrm{~min}$ (Quiñones et al., 2015). Similar to the Fenton's process, the presence of a suitable (inert) catalyst also supports ozonation and increases the ACT removal efficiency. According to a recent report, by applying a modified $\mathrm{MgO}$ catalyst, the $\mathrm{MgO} / \mathrm{O}_{3}$ process showed $\mathrm{ACT}$ degradation and mineralization efficiencies that were 18.8 and 7.8 -fold higher than the sole ozonation process (Mashayekh- 
490

491

492

493

494

495

496

497

498

499

500

501

502

503

504

505

506

507

508

509

510

511

512

513

514

Salehi et al., 2017). Ozonation could also eliminate ACT entirely to the ppt level, but the operation cost of ozonation is comparable to the Fenton's process. The cost of a photo-based Fenton process is $1.56 € / \mathrm{m}^{3}$, whereas the ozone-based process costs $\sim 0.49-0.59 € / \mathrm{m}^{3}$ (Quiñones et al., 2015). Fenton process, when incorporated with modified $\mathrm{TiO}_{2}$ based catalysts can increase the operational costs. In comparision, $\mathrm{MgO}$ is a relatively low-cost and environmentally friendly catalyst that has also been extensively used in the field of environmental engineering.

\subsection{Adsorption processes}

The efficiency of adsorption based processes can be governed by the physico-chemical properties of the adsorbent as well as the chemical reactions occurring at the surface of the adsorbent. Typically, activated carbon is the most commonly used adsorbent that yields relatively stable ACT removal efficiencies. Modified activated carbon based adsorbent includes, chitosan-nano (Amouzgar et al., 2017), granular type (Yanyan et al., 2018) and phosphoric acid modified (Wong et al., 2018) for ACT removal from wastewater. In practice, the adsorption process is assisted with sonication, ozonation and constructed wetlands to enhance the ACT removal efficiency.

Concerning the chitosan nano activated carbon, $94.7 \%$ of ACT, at a concentration of $0.2 \mathrm{mg} / \mathrm{l}$ can be removed from the aqueous solution when its supported by a sonication step (Amouzgar et al., 2017). Another modified activated carbon media is the granular form that is usually derived from coconut shell (Yanyan et al., 2018). In both cases, the breakthrough capacities of the media were reached within 26 - $48 \mathrm{~h}$ of operation, at a concentration of $40-120 \mathrm{mg} \mathrm{ACT} / \mathrm{l}$. The activated carbon developed from spent tea leaves have also been tested for ACT treatment and removal efficiencies $>99 \%$ at an initial concentration of $10 \mathrm{mg} / \mathrm{l}$ was reported (Wong et al., 2018). In large scale systems, a WWTP when combined with a horizontal sub-surface flow wetland removed $>98 \%$ ACT (Verlicchi et al., 2013). In that study, the influent and effluent 
concentrations of ACT were $30 \pm 20$ and $16 \pm 6 \mathrm{ng} / \mathrm{l}$, respectively. In this combined removal process, other removal pathways such as biodegradation, sedimentation and plant uptake are also involved. In a recent study that was aimed at the removal of ACT from drinking water, $20 \%$ ACT was removed in a sand filter and a granular activated carbon (GAC) filter, respectively (Lin et al., 2016c). For a conventional drinking water treatment plant, the average ACT removal efficiency is usually $>96 \%$ (Boleda et al., 2011). Therefore, adsorption is a promising and feasible treatment option that contributes to the good removal of ACT in major drinking water treatment plants.

\subsection{Membrane processes}

Membrane separation process is an emerging technology for ACT removal from different water environments. It is categorized based on the pore size of the membrane and the material of construction. For the pore size, the nanofiltration and reverse osmosis membranes are effective to retain the ACT molecules/particles, rather than the ultrafiltration and microfiltration modules. The pore sizes of nanofiltration and reverse osmosis membranes are less than the size of the ACT molecules. Regarding the fabricated materials, they can either natural or synthetic. The natural material include wool, ceramics, rubber and cellulose. The synthetic membrane include polyethylene amine, metal-organic frameworks (MOF), laccase and polydopamine, polyvinylidene difluoride, hydroxyapatite, cellulose triacetate and polyamide composite. The membrane process can be combined with biological treatment in a membrane bioreactor

534 (MBR). For ACT contaminated ground water, nanofiltration and RO membrane rejected 44.8 $535-73 \%$ ACT (Radjenović et al., 2008). Similarly, hollow fiber MBR removed ACT at lower efficiencies, i.e. $<20 \%$ (Nguyen et al., 2013). The single process of MF can remove $50-90 \%$ of ACT from different water environments (Ba et al., 2014). However, if they are supported by an integrated UV process, NF and RO can completely remove ACT from water. Therefore, a 
539

540

541

542

543

544

545

546

547

548

549

550

551

552

553

554

555

556

557

558

559

560

561

562

563

stand-alone MBR or a microfiltration membrane process is not highly efficient for the treatment of $\mathrm{ACT}$ at high concentrations.

Another improved membrane process is a novel enzyme coating on the surface of membranes to achieve high ACT removal efficiencies. For example, cross-linked enzyme aggregates of laccase were doped on a polysulfone hollow fiber MF membrane to remove ACT $(>99 \%)$ at concentrations $<0.1 \mathrm{mg} / 1$ (Ba et al., 2014).

\subsection{Hybrid processes}

The hybrid process (treatment train) incorporates different technologies such as a biological process, plant uptake, membrane filtration, adsorption and AOPs. In this combined process, the biological processes such as anaerobic/aerobic/oxic $\left(\mathrm{A}_{2} \mathrm{O}\right)$ would be placed first (as a pretreatment step) to reduce the pollutant load, followed by either AOP, plant uptake, adsorption and membrane process.

As an example, at the Alcalá de Henares WWTP (Madrid, Spain), the $\mathrm{A}_{2} \mathrm{O}$ process was coupled with ozonation to eliminate ACT from wastewater (Rosal et al., 2010). For this case, the $\mathrm{A}_{2} \mathrm{O}$ process removed ACT to below detection limits, thus, ozonation was rarely used. Similarly, an integrated system of anoxic/aerobic process and MFC was able to remove $>98 \%$ ACT at a concentration of $30 \mathrm{mg} / 1$ (Chang et al., 2014). In another study, at the pilot scale, the integrated process removed $\sim 94-99.9 \%$ ACT at initial concentrations varying between $2.6-300 \mu \mathrm{g} / \mathrm{l}$ (Gallardo-Altamirano et al., 2018). According to the authors, long-term experiments confirmed that the operating and environmental conditions of $\mathrm{A}_{2} \mathrm{O}$ did not affect the ACT removal efficiency. It is noteworthy to mention that, for the hybrid system, each technology contributes differently during the ACT removal process. For example, $\mathrm{A}_{2} \mathrm{O}$ contributes to $\sim 77 \%$ of the 97\% ACT removed during the entire process, whereas chlorine disinfection accounted for the remaining 20\% ACT removed (Kosma et al., 2010). In a case study involving five WWTPs from Ulsan city (South Korea), the primary treatment process removed 28\% of the total PPCPs, 
564

565

566

567

568

569

570

571

572

573

574

575

576

577

578

579

580

581

582

583

584

585

586

587

588

including ACT, and the biological treatment process used in the WWTP was recognized as the main process that ensured $>99 \%$ ACT removal in the WWTPs (Behera et al., 2011).

\subsection{Other processes}

Apart from the above mentioned and illustrated technologies, the non-conventional technologies include ultrasonic treatment (Villaroel et al., 2014) and zero valent aluminum (Zhang et al., 2012). Ultrasonic treatment could degrade ACT to inorganic compounds competitively when compared to other technologies (Villaroel et al., 2014). For instance, ACT was completely removed after $180 \mathrm{~min}$ at initial concentrations varying between 33 to 1323 $\mu \mathrm{mol} / \mathrm{l}$. In the case of zero valent aluminium technology, the commercial zero valent aluminum under air-equilibrated acidic conditions eliminated $>99 \%$ ACT, at a concentration of $2 \mathrm{mg} / 1$ and a contact time of $16 \mathrm{~h}$ (Zhang et al., 2012). Although these processes are applicable for ACT removal from contaminated water sources, full-scale applications of this process has never been demonstrated due to cost and scale-up implications.

\subsection{Comparison of technologies}

In practice, all the technologies mentioned in this review could be a part of the WWTP train. Their application would depend on the characteristics of the wastewater, initial ACT concentration, local environmental conditions and the effluent discharge standards. Overall, the biological process (aerobic/anaerobic) is suitable for secondary treatment and it can reduce the ACT concentration from the ppm to ppb levels. The adsorption, AOP, membrane process and plant uptake are rather meant specifically for tertiary treatment. These technologies can act as a post-treatment or polishing step to reduce the ACT concentration from the ppb to ppt level. When space is a constraint at the field-scale, membrane, AOP and adsorption technologies are feasible options. However, in the case of membrane reactors, fouling is a major concern and it also requires high operation and maintanence skills. In the case of AOP and adsorption, chemical consumption and secondary pollution (e.g. due to metabolites) are the major concerns 
589

590

591

592

593

594

595

596

597

598

599

600

601

602

603

604

605

606

607

608

609

610

611

612

613

that will add to the operating costs. In a spacious WWTP, CWs can be considered as a dependable solution.

Most technologies remove ACT efficiently in the range of $80-100 \%$ (Fig. 2). However, plant uptake and membrane process perform less with average removal efficiencies in the range of $\sim 60 \%$. For example, at a ACT concentration of $1200 \mathrm{mg} / \mathrm{l}$, an external airlift membrane bioreactor (MBR) removed ACT better than an activated sludge process (Shariati et al., 2010). Within $2 \mathrm{~d}$ of continuous operation, the external airlift MBR treated $100 \%$ ACT, while the activated sludge was able to perform only with $50 \%$ efficiency. The mechanism of the MBR system involves biodegradation, adsorption and filtration process, whereas biological activity was the sole mechanism governing the removal of ACT in the activated sludge process.

Nevertheless, high removal efficiency does not necessarily mean that ACT is removed completely from the aqueous (water) phase because it can be degraded and transformed into other less toxic or more toxic metabolites. In brief, the following salient features were recognized based on this review on ACT: (i) biological processes can deal with high concentrations of ACT in wastewater $(1200 \mathrm{mg} / \mathrm{l})$, however, the biodegradation process requires more time and ACT is not reduced to the ppt levels; (ii) AOPs can degrade ACT at high degradation rates to the ppt levels, but they are rather expensive and might lead to the formation of toxic intermediates, and (iii) other technologies such as plant uptake, adsorption and membrane processes can be integrated with biological process to reduce ACT to the desired ppt levels.

[Insert Fig. 2]

\section{By-products transformation and degradation pathways}

During wastewater treatment, ACT can be degraded/transformed to several metabolites. As explained previously, some of these intermediates can be more detrimental to human health and the ecological system than the parent ACT compound (Bedner and MacCrehan, 2006). By 
614

615

616

617

618

619

620

621

622

623

624

625

626

627

628

629

630

631

632

633

634

635

636

637

applying the existing analytical technologies, some of these metabolites are not adequately detected in the influent wastewater and the treated effluent. Thus, identification of ACT intermediates and their metabolic pathways is essential to evaluate their potential impacts on human health, the environment and other aquatic life forms.

\subsection{Mechanisms of acetaminophen transformation}

ACT molecules consist of an aromatic phenol ring with an acetamido substitution at the paraposition (Fig. 3). These components are targets for the invasion of oxidizing agents such as ${ }^{\circ} \mathrm{OH}, \mathrm{CO}_{3}{ }^{-}$and $\mathrm{ClO}^{-}$, photon energy and ferrate (VI).

[Insert Fig. 3]

The most striking oxidative agent that helps in breaking the aromatic ring is ${ }^{\circ} \mathrm{OH}$. It would invade the aromatic bonds first during the photo-Fenton process (Trovó et al., 2012). Similarly, $\mathrm{O}_{3}$ and/or $\cdot \mathrm{OH}$ agents can attack the aromatic ring through normal and ipso mechanisms, following by a series of oxidation processes (Zhang et al. 2008; de Luna et al., 2012; Wang et al., 2016a). These processes open the ring core and cleave the phenol-acetamido bond. Similar to hydroxyl radicals, $\mathrm{ClO}^{-}$and ferrate (VI) can also attack the benzene ring or the phenolacetamido bonds (Bedner and MacCrehan, 2006; Wang et al., 2016a). This gives rise to a wide range of ACT metabolites such as hydroquinone, 2-hydroxy-4-(N-acetyl)-aminophenol, or dicarboxylic acids. These metabolites can exhibit both toxic and non-toxic characteristics (Table 5). In addition, the phenol-acetamido and NH-CO amide bonds are also the targets of the oxidative agents. The phenol-acetamido bond can be invaded by $\mathrm{CO}_{3}{ }^{-}, \mathrm{ClO}^{-}$and ferrate (VI), while the ferrate (VI) and photon energy breaks down the NH-CO bond (Bedner and MacCrehan, 2006; De Laurentiis et al., 2014; Chang et al., 2015; Wang et al., 2016a). Thereafter, acetamide and/or acetamide derivatives are formed from the acetamido group of ACT. 
Unlike chemical treatment where oxidizing reagents are employed, bioenzymes are the driving agents to degrade or transform ACT in biological treatment systems. For instance, monooxygenases such as flavin-containing hydroxylases or cytochromes P-450 could degrade ACT efficienctly in different water environments ( $\mathrm{Li}$ et al., 2014). While the biodegradation intermediates and/or end-products of ACT are somewhat similar to chemical degradation processes, the mechanism involved in these two processes are entirely different. For example, in a microbial fuel cell (MFC) - Fenton system, the acetamido moiety was the preferable target of bioenzymes rather than the aromatic ring (Zhang et al., 2015). Firstly, the phenol-acetamido bond was hydrolyzed by bio-electrons and protons to form p-aminophenol and acetic acid, respectively. Subsequently, $p$-aminophenol was oxidized by the ${ }^{\circ} \mathrm{OH}$ radicals forming various by-products (Zhang et al., 2015).

In brief, the exact intermediates and end-products of ACT formed largely depends on the degradation mechanism and the pathway. Therefore, one should consider what treatment system would be employed to predict the transformation pathways and intermediates of ACT. These information are essential to evaluate the suitability and sustainability of such systems in full-scale applications.

\subsection{Aromatic intermediates}

The first point of attack during ACT degradation often takes place on the aromatic ring or the acetamido moiety as discussed earlier. In this stage, ring cleavage does not occur and the byproducts are often of aromatic nature (Fig. 4). However, the exact intermediates formed depend only on the treatment (physical/chemical or biological) system used.

\section{[Insert Fig. 4]}

During the AOP processes, 1,4-benzoquinone, hydroquinone and amides were the main intermediates of ACT regardless of the applied technologies (Andreozzi et al., 2003; de Luna et al., 2012; Chang et al., 2015). However, other intermediates were also reported to be formed 
663

664

665

666

667

668

669

670

671

672

673

674

675

676

677

678

679

680

681

682

683

684

685

686

in different technologies, especially alcoholic substances. For example, in a photocatalytic treatment process, the major intermediates were hydroquinone, 1,4-benzoquinone, 1-(2hydroxyphenyl-5-amino) ethanone and 1-(2-amino-5-hydroxyphenyl) ethanone (Chang et al., 2015). On the other hand, $\mathrm{H}_{2} \mathrm{O}_{2} / \mathrm{UV}$ systems generated 1-(2-amino-5-hydroxyphenyl) ethanone, (N-(3,4-dihydroxyphenyl) acetamide, and 1-(2-amino-5-hydroxyphenyl) ethanone (Andreozzi et al. 2003; Feng et al., 2015). Notably, the $\mathrm{H}_{2} \mathrm{O}_{2} / \mathrm{UV}$ system did not generate the toxic compound $N$-acetyl-para-benzoquinone imine (NAPQI). Therefore, it is a recommended technology to avoid the formation of NAPQI. In turn, hypochlorination disinfection should be applied cautiously since at least 11 by-products of ACT were reported including two toxic compounds 1,4-benzoquinone and NAPQI (Bedner and MacCrehan, 2006). As reported in the liteatures, these compounds are even more toxic than ACT.

On the other hand, when the MBR technology was applied, sulfate-related intermediates of ACT were identified: acetaminophen-O-sulphate $\left(\mathrm{C}_{8} \mathrm{H}_{9} \mathrm{O}_{5} \mathrm{NS}\right)$, acetaminophen-glutathione $\left(\mathrm{C}_{18} \mathrm{H}_{24} \mathrm{O}_{8} \mathrm{~N}_{4} \mathrm{~S}\right)$, and transformation product $\left(\mathrm{C}_{12} \mathrm{H}_{10} \mathrm{O}_{2} \mathrm{~N}\right)$ of acetaminophen-glutathione (Tambosi et al., 2010). These compounds are popular intermediates in WWTPs and also formed from human detoxification and excretion processes. In contrast, De Gusseme et al. (2011) reported that hydroquinone was the only by-product of ACT degradation in a membrane reactor.

In soil environments, microorganisms play a critical role as a biocatalyst for ACT mineralization. Li et al. (2014) detected 8 aromatic intermediates of ACT in soil such as 3hydroxyacetaminophen, hydroquinone and 1,4-benzoquinone, respectively. Similar mechanism can also potentially occur in ACT contaminated sludge of WWTPs. Interestingly, in both environments, hydroquinone and 1,4-benzoquinone are the most commonly detected intermediates. 
687

688

689

690

691

692

693

694

695

696

697

698

699

700

701

702

703

704

705

706

707

708

709

710

711

\subsection{Ring-opening and inorganic intermediates}

During the first step of the degradation stage, oxidative agents attack the different functional groups and bonds of the ACT molecule including the hydroxyl group, acetamido group and the phenolic ring. For example, ${ }^{\circ} \mathrm{OH}$ in a bio-electrochemical system oxidizes the hydroxyl group of the phenol ring creating intermediates such as maleic, malonic, malic and lactic acid, respectively (Zhang et al., 2015). Organic carboxylic acids were also observed to be intermediates of the ACT degradation process by other researchers (Andreozzi et al., 2003; de Luna et al., 2012; de Luna et al., 2013). In a fluidized-bed reactor employing the Fenton's process, $\mathrm{NH}_{4}{ }^{+}$, formic acid and 1,2-pentanediol were identified as the main ACT degradation products (de Luna et al., 2013). Similarly, ferrate (VI) reacts with the acetamido group and the aromatic intermediates of ACT to form $\mathrm{NO}_{3}^{-}$, maleic acid, oxalic acid and formic acid, respectively (Wang et al., 2016a). Following the oxidation of ACT to organic acids, $\mathrm{CO}_{2}$ was ascertained as a final mineralized product (Zhang et al., 2012). Thus, briefly stating, ringopening of ACT and ACT by-products will eventually lead to the formation of different types of organic acids. Further oxidation of these acids, acetamide, and acetamide derivatives would only result in complete mineralization of $\mathrm{ACT}$ into $\mathrm{NH}_{4}{ }^{+}, \mathrm{NO}_{3}{ }^{-}$, and $\mathrm{CO}_{2}$, respectively.

\subsection{Polymeric intermediates}

Polymeric intermediates are usually prevalent and noticed in soil environments (Liang et al., 2016). ACT molecules can interact with each other at either the ortho, para, or amide bonding positions giving rise to numerous dimer and trimer intermediates. For example, nine dimer and trimer intermediates of ACT were discovered in soil (Li et al., 2014). Importantly, a low pH and warm environmental condition will accelerate the ACT polymerization reaction (Xiao et al., 2013). The degradation process would be largely dependent on the soil types, activity of the microorganism, enzymes secreted during the biodegradation processes, $\mathrm{pH}$, moisture content of soil, soil porosity, oxygen availability, and the initial ACT concentration. 
712

713

714

715

716

717

718

719

720

721

722

723

724

725

726

727

728

729

730

731

732

733

734

735

736

Recently, more than 20 intermediates formed during the ACT removal process was reported in the literature. Compounds such as 4-benzoquinone and NAPQI are more toxic than ACT, while some compounds such as $\mathrm{NH}_{4}{ }^{+}, \mathrm{CO}_{2}$, and $\mathrm{NO}_{3}{ }^{-}$are rather less toxic. As observed from the review, the dimer and trimer by-products were also detected, particularly in the soil environment. According to the information presented in Table 5, AOP was the only technology that is capable of degrading ACT to innocuous inorganic end-products. Thus, AOP can be recommended to be applied in WWTPs as a tertiary treatment step. The salient remarks on ACT transformation products and metabolites in environments can be stated as follows: (i) the oxidative agents capable of removing $\mathrm{ACT}$ include ${ }^{\circ} \mathrm{OH}, \mathrm{O}_{3}, \mathrm{ClO}^{-}$, photon energy and bioenzymes; (ii) the oxidative agents attack and cleave the aromatic ring and acetamido moiety of ACT to form more than 20 aromatic and inorganic intermediates; and (iii) polymeric intermediates are only formed in soil environments.

[Insert Table 5]

\section{Conclusions}

Historically, ACT pollution has occurred in many countries, at various concentrations and detection frequencies and ACT concentration in wastewater has increased significantly since the year of 1998. China and the USA are the two countries with concerned ACT levels and detection frequencies in wastewater. However, ACT concentration in drinking water has decreased significantly from ppb to ppt levels due to advancements in wastewater treatment systems. Concerning the implementation of policies, European countries and the United States have developed different management policies and legislations/standards for the discharge of micropollutants and their prevention, while the legislation are rather not stringent in most of the Asian countries due to lack of reliable historic data. In addition, to ensure ACT free drinking water source, the application of advanced and hybrid technologies is urgently required at the field scale because ACT can transform to more than 20 different intermediates and end- 
737

738

739

740

741

742

743

744

745

746

747

748

749

750

751

752

753

754

755

756

757

758

759

products. Anew, ensuring ACT levels less than $71 \mathrm{ng} / 1$ in drinking water is still a challenging task as it will require extensive investment costs, technical and management expertise.

\section{Acknowledgements}

The authors would thank IHE-Delft (The Netherlands) for providing staff time support to collaborate with researchers from Vietnam under the project 'Support to Society'. Also, the author would like to thank Ms. Khanh-Dieu Hoang for her support in data collection.

\section{References}

1. Alvarino, T., Katsou, E., Malamis, S., Suarez, S., Omil, F., Fatone, F., 2014. Inhibition of biomass activity in the via nitrite nitrogen removal processes by veterinary pharmaceuticals. Bioresource Technology, 152, 477-483.

2. Amouzgar, P., Chan, E.-S., Salamatinia, B., 2017. Effects of ultrasound on development of Cs/NAC nano composite beads through extrusion dripping for acetaminophen removal from aqueous solution. Journal of Cleaner Production, 165, 537-551.

3. Andreozzi, R., Caprio, V., Marotta, R., Vogna, D., 2003. Paracetamol oxidation from aqueous solutions by means of ozonation and $\mathrm{H}_{2} \mathrm{O}_{2} / \mathrm{UV}$ system. Water Research, 37(5), 993-1004.

4. Arredondo Valdez, H.C., García Jiménez, G., Gutiérrez Granados, S., Ponce de León, C., 2012. Degradation of paracetamol by advance oxidation processes using modified reticulated vitreous carbon electrodes with $\mathrm{TiO}_{2}$ and $\mathrm{CuO} / \mathrm{TiO}_{2} / \mathrm{Al}_{2} \mathrm{O}_{3}$. Chemosphere, 89(10), 1195-1201.

5. Ba, S., Jones, J.P., Cabana, H., 2014. Hybrid bioreactor (HBR) of hollow fiber microfilter membrane and cross-linked laccase aggregates eliminate aromatic pharmaceuticals in wastewaters. Journal of Hazardous materials, 280, 662-670. 
760

761

762

763

764

765

766

767

768

769

770

771

772

773

774

775

776

777

778

779

780

781

782

783

6. Baron, P.A., Love, D.C., Nachman, K.E., 2014. Pharmaceuticals and personal care products in chicken meat and other food animal products: A market-basket pilot study. Science of the Total Environment, 490, 296-300.

7. Bartha, B., Huber, C., Harpaintner, R., Schröder, P., 2010. Effects of acetaminophen in Brassica juncea L. Czern.: investigation of uptake, translocation, detoxification, and the induced defense pathways. Environmental Science and Pollution Research, 17(9), 15531562.

8. Basavaraju, M., Mahamood, S., Vittal, H., Shrihari, S., 2011. A novel catalytic route to degrade paracetamol by Fenton process. International Journal of Research in Chemistry and Environment, 1(1), 157-164.

9. Bedner, M., MacCrehan, W.A., 2006. Transformation of Acetaminophen by Chlorination Produces the Toxicants 1,4-Benzoquinone and N-Acetyl-p-benzoquinone Imine. Environmental Science \& Technology, 40(2), 516-522.

10. Behera, S.K., Kim, H.W., Oh, J.-E., Park, H.-S., 2011. Occurrence and removal of antibiotics, hormones and several other pharmaceuticals in wastewater treatment plants of the largest industrial city of Korea. Science of the Total Environment, 409(20), 43514360.

11. Blair, B.D., Crago, J.P., Hedman, C.J., Klaper, R.D., 2013a. Pharmaceuticals and personal care products found in the Great Lakes above concentrations of environmental concern. Chemosphere, 93(9), 2116-2123.

12. Blair, B.D., Crago, J.P., Hedman, C.J., Treguer, R.J.F., Magruder, C., Royer, L.S., Klaper, R.D., 2013. Evaluation of a model for the removal of pharmaceuticals, personal care products, and hormones from wastewater. Science of the Total Environment, 444, $515-521$ 
784

785

786

787

788

789

790

791

792

793

794

795

796

797

798

799

800

801

802

803

804

805

806

807

13. Boleda, M.R., Galceran, M.T., Ventura, F., 2011. Behavior of pharmaceuticals and drugs of abuse in a drinking water treatment plant (DWTP) using combined conventional and ultrafiltration and reverse osmosis (UF/RO) treatments. Environmental Pollution, 159(6), 1584-1591.

14. Botero-Coy, A., Martínez-Pachón, D., Boix, C., Rincón, R., Castillo, N., Arias-Marín, L., Manrique-Losada, L., Torres-Palma, R., Moncayo-Lasso, A., Hernández, F.J.S.o.T.T.E., 2018. An investigation into the occurrence and removal of pharmaceuticals in Colombian wastewater. 642, 842-853.

15. Boyd, G.R., Reemtsma, H., Grimm, D.A., Mitra, S., 2003. Pharmaceuticals and personal care products (PPCPs) in surface and treated waters of Louisiana, USA and Ontario, Canada. Science of the Total Environment, 311(1), 135-149.

16. Cantwell, M.G., Katz, D.R., Sullivan, J.C., Shapley, D., Lipscomb, J., Epstein, J., Juhl, A.R., Knudson, C., O'Mullan, G.D., 2018. Spatial patterns of pharmaceuticals and wastewater tracers in the Hudson River Estuary. Water Research, 137, 335-343.

17. Chang, C.-T., Wang, J.-J., Ouyang, T., Zhang, Q., Jing, Y.-H., 2015. Photocatalytic degradation of acetaminophen in aqueous solutions by $\mathrm{TiO}_{2} / \mathrm{ZSM}-5$ zeolite with low energy irradiation. Materials Science and Engineering: B, 196, 53-60.

18. Chang, Y.-T., Yang, C.-W., Chang, Y.-J., Chang, T.-C., Wei, D.-J., 2014. The Treatment of PPCP-Containing Sewage in an Anoxic/Aerobic Reactor Coupled with a Novel Design of Solid Plain Graphite-Plates Microbial Fuel Cell. BioMed Research International, 2014, 13.

19. Choi, K., Kim, Y., Park, J., Park, C.K., Kim, M., Kim, H.S., Kim, P., 2008. Seasonal variations of several pharmaceutical residues in surface water and sewage treatment plants of Han River, Korea. Science of the Total Environment, 405(1-3), 120-128. 
20. Choi, M., Furlong, E.T., Werner, S.L., Pait, A.S., Lee, I.-S., Choi, H.-G., 2014. Cimetidine, acetaminophen, and 1,7-dimethylxanthine, as indicators of wastewater pollution in marine sediments from Masan Bay, Korea. Ocean Science Journal, 49(3), 231-240.

21. Conley, J.M., Symes, S.J., Schorr, M.S., Richards, S.M., 2008. Spatial and temporal analysis of pharmaceutical concentrations in the upper Tennessee River basin. Chemosphere, 73(8), 1178-1187.

22. Daniel, C.-Y.W., Wan-Loy, C., Yih-Yih, K., 2015. Assessment of Paracetamol (Acetaminophen) Toxicity in Microalgae. Polish Journal of Environmental Studies 24(2), 735-741.

23. De Gusseme, B., Vanhaecke, L., Verstraete, W., Boon, N., 2011. Degradation of acetaminophen by Delftia tsuruhatensis and Pseudomonas aeruginosa in a membrane bioreactor. Water Research, 45(4), 1829-1837.

24. De Laurentiis, E., Prasse, C., Ternes, T.A., Minella, M., Maurino, V., Minero, C., Sarakha, M., Brigante, M., Vione, D., 2014. Assessing the photochemical transformation pathways of acetaminophen relevant to surface waters: Transformation kinetics, intermediates, and modelling. Water Research, 53, 235-248.

25. de Luna, M.D.G., Briones, R.M., Su, C.-C., Lu, M.-C., 2013. Kinetics of acetaminophen degradation by Fenton oxidation in a fluidized-bed reactor. Chemosphere, 90(4), 14441448.

26. de Luna, M.D.G., Veciana, M.L., Su, C.-C., Lu, M.-C., 2012. Acetaminophen degradation by electro-Fenton and photoelectro-Fenton using a double cathode electrochemical cell. Journal of Hazardous Materials, 217-218, 200-207. 
27. Del Río, H., Suárez, J., Puertas, J., Ures, P., 2013. PPCPs wet weather mobilization in a combined sewer in NW Spain. Science of the Total Environment, 449, 189-198.

28. Feng, S., Zhang, X., Liu, Y., 2015. New insights into the primary phototransformation of acetaminophen by $\mathrm{UV} / \mathrm{H}_{2} \mathrm{O}_{2}$ : photo-Fries rearrangement versus hydroxyl radical induced hydroxylation. Water Research, 86, 35-45.

29. Ferguson, P.J., Bernot, M.J., Doll, J.C., Lauer, T.E., 2013. Detection of pharmaceuticals and personal care products (PPCPs) in near-shore habitats of southern Lake Michigan. Science of the Total Environment, 458-460, 187-196.

30. Fisher, E.S., Curry, S.C. 2019. Evaluation and Treatment of Acetaminophen Toxicity. in: Adv. Pharmacol., Academic Press.

31. Fram, M.S., Belitz, K., 2011. Occurrence and concentrations of pharmaceutical compounds in groundwater used for public drinking-water supply in California. Science of the Total Environment, 409(18), 3409-3417.

32. Gallardo-Altamirano, M.J., Maza-Márquez, P., Peña-Herrera, J.M., Rodelas, B., Osorio, F., Pozo, C., 2018. Removal of anti-inflammatory/analgesic pharmaceuticals from urban wastewater in a pilot-scale A2O system: Linking performance and microbial population dynamics to operating variables. Science of The Total Environment, 643, 1481-1492.

33. Gao, J., O'Brien, J., Du, P., Li, X., Ort, C., Mueller, J.F., Thai, P.K., 2016. Measuring selected PPCPs in wastewater to estimate the population in different cities in China. Science of the Total Environment, 568, 164-170.

34. Gros, M., Petrović, M., Ginebreda, A., Barceló, D., 2010. Removal of pharmaceuticals during wastewater treatment and environmental risk assessment using hazard indexes. Environment International, 36(1), 15-26. 
35. Grujić, S., Vasiljević, T., Laušević, M., 2009. Determination of multiple pharmaceutical classes in surface and ground waters by liquid chromatography-ion trap-tandem mass spectrometry. Journal of Chromatography A, 1216(25), 4989-5000.

36. He, K., Echigo, S., Itoh, S., 2016. Effect of operating conditions in soil aquifer treatment on the removals of pharmaceuticals and personal care products. Science of the Total Environment, 565, 672-681.

37. He, Y., Dong, Y., Huang, W., Tang, X., Liu, H., Lin, H., Li, H., 2015. Investigation of boron-doped diamond on porous Ti for electrochemical oxidation of acetaminophen pharmaceutical drug. Journal of Electroanalytical Chemistry, 759, Part 2, 167-173.

38. Hedgespeth, M.L., Sapozhnikova, Y., Pennington, P., Clum, A., Fairey, A., Wirth, E., 2012. Pharmaceuticals and personal care products (PPCPs) in treated wastewater discharges into Charleston Harbor, South Carolina. Science of the Total Environment, 437, 1-9.

39. Henschel, K.P., Wenzel, A., Diedrich, M., Fliedner, A., 1997. Environmental Hazard Assessment of Pharmaceuticals. Regulatory Toxicology and Pharmacology, 25(3), 220225.

40. Huber, C., Bartha, B., Harpaintner, R., Schröder, P., 2009. Metabolism of acetaminophen (paracetamol) in plants - two independent pathways result in the formation of a glutathione and a glucose conjugate. Environmental Science and Pollution Research, 16(2), 206-213.

41. Im, J.-K., Yoon, J., Her, N., Han, J., Zoh, K.-D., Yoon, Y., 2015. Sonocatalytic-TiO 2 nanotube, Fenton, and $\mathrm{CCl} 4$ reactions for enhanced oxidation, and their applications to acetaminophen and naproxen degradation. Separation and Purification Technology, 141, $1-9$. 
42. Kasprzyk-Hordern, B., Dinsdale, R.M., Guwy, A.J., 2008. The occurrence of pharmaceuticals, personal care products, endocrine disruptors and illicit drugs in surface water in South Wales, UK. Water Research, 42(13), 3498-3518.

43. Kasprzyk-Hordern, B., Dinsdale, R.M., Guwy, A.J., 2009. The removal of pharmaceuticals, personal care products, endocrine disruptors and illicit drugs during wastewater treatment and its impact on the quality of receiving waters. Water Research, 43(2), 363-380.

44. Kim, I., Tanaka, H., 2009. Photodegradation characteristics of PPCPs in water with UV treatment. Environment International, 35(5), 793-802.

45. Kim, J.W., Yoon, S.M., Lee, S.J., Narumiya, M., Nakada, N., Han, I.S., Tanaka, H. 2012. Occurrence and Fate of PPCPs Wastewater Treatment Plants in Korea. in: 2nd International Conference on Environment and Industrial Innovation, Vol. 35, IACSIT Press, Singapore.

46. Kim, S.D., Cho, J., Kim, I.S., Vanderford, B.J., Snyder, S.A., 2007a. Occurrence and removal of pharmaceuticals and endocrine disruptors in South Korean surface, drinking, and waste waters. Water Research, 41(5), 1013-1021.

47. Kim, Y., Choi, K., Jung, J., Park, S., Kim, P.-G., Park, J., 2007b. Aquatic toxicity of acetaminophen, carbamazepine, cimetidine, diltiazem and six major sulfonamides, and their potential ecological risks in Korea. Environment International, 33(3), 370-375.

48. Kolpin, D.W., Furlong, E.T., Meyer, M.T., Thurman, E.M., Zaugg, S.D., Barber, L.B., Buxton, H.T., 2002. Pharmaceuticals, Hormones, and Other Organic Wastewater Contaminants in U.S. Streams, 1999-2000: A National Reconnaissance. Environmental Science \& Technology, 36(6), 1202-1211. 
901

902

903

904

905

906

907

908

909

910

911

912

913

914

915

916

917

918

919

920

921

922

923

49. Kosma, C.I., Lambropoulou, D.A., Albanis, T.A., 2010. Occurrence and removal of PPCPs in municipal and hospital wastewaters in Greece. Journal of Hazardous materials, 179(1-3), 804-817.

50. Kosma, C.I., Lambropoulou, D.A., Albanis, T.A., 2014. Investigation of PPCPs in wastewater treatment plants in Greece: Occurrence, removal and environmental risk assessment. Science of the Total Environment, 466-467, 421-438.

51. Kurniawan, T.A., Yanyan, L., Ouyang, T., Albadarin, A.B., Walker, G., 2018. $\mathrm{BaTiO}_{3} / \mathrm{TiO}_{2}$ composite-assisted photocatalytic degradation for removal of acetaminophen from synthetic wastewater under UV-vis irradiation. Materials Science in Semiconductor Processing, 73, 42-50.

52. Lapworth, D.J., Baran, N., Stuart, M.E., Ward, R.S., 2012. Emerging organic contaminants in groundwater: A review of sources, fate and occurrence. Environmental Pollution, 163, 287-303.

53. Li, J., Ye, Q., Gan, J., 2014. Degradation and transformation products of acetaminophen in soil. Water Research, 49, 44-52.

54. Liang, C., Lan, Z., Zhang, X., Liu, Y., 2016. Mechanism for the primary transformation of acetaminophen in a soil/water system. Water Research, 98, 215-224.

55. Lin, A.Y.-C., Tsai, Y.-T., 2009. Occurrence of pharmaceuticals in Taiwan's surface waters: Impact of waste streams from hospitals and pharmaceutical production facilities. Science of the Total Environment, 407(12), 3793-3802.

56. Lin, C.J., Yang, W.-T., Chou, C.-Y., Liou, S.Y.H., 2016a. Hollow mesoporous $\mathrm{TiO}_{2}$ microspheres for enhanced photocatalytic degradation of acetaminophen in water. Chemosphere, 152, 490-495. 
57. Lin, J.C.-T., de Luna, M.D.G., Aranzamendez, G.L., Lu, M.-C., 2016b. Degradations of acetaminophen via a $\mathrm{K}_{2} \mathrm{~S}_{2} \mathrm{O}_{8}$-doped $\mathrm{TiO}_{2}$ photocatalyst under visible light irradiation. Chemosphere, 155, 388-394.

58. Lin, T., Yu, S., Chen, W., 2016c. Occurrence, removal and risk assessment of pharmaceutical and personal care products (PPCPs) in an advanced drinking water treatment plant (ADWTP) around Taihu Lake in China. Chemosphere, 152, 1-9.

59. Lutpi, N.A.A., Yuzir, M.A.M., Yong, E.L., Salim, M.R., Yusop, Z., Salmiati, 2015. The effect of water quality on removal of acetaminophen in surface water by ozonation process. Jurnal Teknologi, 74(11), 1-7.

60. Lv, M., Sun, Q., Hu, A., Hou, L., Li, J., Cai, X., Yu, C.-P., 2014. Pharmaceuticals and personal care products in a mesoscale subtropical watershed and their application as sewage markers. Journal of Hazardous materials, 280, 696-705.

61. Manu, B. and Mahamood, 2011. Degradation of paracetamol in aqueous solution by Fenton Oxidation and photo-Fenton Oxidation processes using iron from Laterite soil as catalyst. International Journal of Earth Sciences and Engineering, 4(6), 1103-1110.

62. Mashayekh-Salehi, A., Moussavi, G., Yaghmaeian, K., 2017. Preparation, characterization and catalytic activity of a novel mesoporous nanocrystalline $\mathrm{MgO}$ nanoparticle for ozonation of acetaminophen as an emerging water contaminant. Chemical Engineering Journal, 310, 157-169.

63. Matamoros, V., Gutiérrez, R., Ferrer, I., García, J., Bayona, J.M., 2015. Capability of microalgae-based wastewater treatment systems to remove emerging organic contaminants: A pilot-scale study. Journal of Hazardous materials, 288, 34-42. 
64. Narumiya, M., Nakada, N., Yamashita, N., Tanaka, H., 2013. Phase distribution and removal of pharmaceuticals and personal care products during anaerobic sludge digestion. Journal of Hazardous materials, 260, 305-312.

65. Nguyen, L.N., Hai, F.I., Kang, J., Price, W.E., Nghiem, L.D., 2013. Removal of emerging trace organic contaminants by MBR-based hybrid treatment processes. International Biodeterioration \& Biodegradation, 85, 474-482.

66. Nunes, B., Pinto, G., Martins, L., Goncalves, F., Antunes, S.C., 2014. Biochemical and standard toxic effects of acetaminophen on the macrophyte species Lemna minor and Lemna gibba. Environ Sci Pollut Res Int, 21(18), 10815-22.

67. Oliveira, T.S., Murphy, M., Mendola, N., Wong, V., Carlson, D., Waring, L., 2015. Characterization of Pharmaceuticals and Personal Care products in hospital effluent and waste water influent/effluent by direct-injection LC-MS-MS. Science of the Total Environment, 518-519, 459-478.

68. Ortiz de García, S., Pinto Pinto, G., García Encina, P., Irusta Mata, R., 2013. Consumption and occurrence of pharmaceutical and personal care products in the aquatic environment in Spain. Science of the Total Environment, 444, 451-465.

69. Papageorgiou, M., Kosma, C., Lambropoulou, D., 2016. Seasonal occurrence, removal, mass loading and environmental risk assessment of 55 pharmaceuticals and personal care products in a municipal wastewater treatment plant in Central Greece. Science of the Total Environment, 543, 547-569.

70. Pedrouzo, M., Reverte, S., Borrull, F., Pocurull, E., Marce, R.M., 2007. Pharmaceutical determination in surface and wastewaters using high-performance liquid chromatography-(electrospray)-mass spectrometry. Journal of Separation Science, 30(3), 297-303. 
970

971

972

973

976

977

978

980

981

982

983

984

985

986

987

988

989

990

991

71. Phong, V.H.N., Koottatep, T., Chapagain, S.K., Panuvatvanich, A., Polprasert, C., Ahn, K.-H., 2016. Removal of acetaminophen from wastewater by constructed wetlands with Scirpus validus. Environmental Engineering Research, 21(2), 164-170.

72. Quiñones, D.H., Álvarez, P.M., Rey, A., Beltrán, F.J., 2015. Removal of emerging contaminants from municipal WWTP secondary effluents by solar photocatalytic ozonation. A pilot-scale study. Separation and Purification Technology, 149, 132-139.

73. Rabiet, M., Togola, A., Brissaud, F., Seidel, J.L., Budzinski, H., Elbaz-Poulichet, F., 2006. Consequences of treated water recycling as regards pharmaceuticals and drugs in surface and ground waters of a medium-sized Mediterranean catchment. Environmental Science and Technology, 40(17), 5282-8.

74. Radjenović, J., Petrović, M., Ventura, F., Barceló, D., 2008. Rejection of pharmaceuticals in nanofiltration and reverse osmosis membrane drinking water treatment. Water Research, 42(14), 3601-3610.

75. Ranieri, E., Verlicchi, P., Young, T.M., 2011. Paracetamol removal in subsurface flow constructed wetlands. Journal of Hydrology, 404(3-4), 130-135.

76. Roberts, P.H., Thomas, K.V., 2006. The occurrence of selected pharmaceuticals in wastewater effluent and surface waters of the lower Tyne catchment. Science of the Total Environment, 356(1-3), 143-153.

77. Rosal, R., Rodríguez, A., Perdigón-Melón, J.A., Petre, A., García-Calvo, E., Gómez, M.J., Agüera, A., Fernández-Alba, A.R., 2010. Occurrence of emerging pollutants in urban wastewater and their removal through biological treatment followed by ozonation. Water Research, 44(2), 578-588. 
992

993

994

995

996

997

998

999

1000

1001

1002

1003

1004

1005

1006

1007

1008

1009

1010

1011

1012

1013

78. Shariati, F.P., Mehrnia, M.R., Salmasi, B.M., Heran, M., Wisniewski, C., Sarrafzadeh, M.H., 2010. Membrane bioreactor for treatment of pharmaceutical wastewater containing acetaminophen. Desalination, 250(2), 798-800.

79. Sim, W.-J., Lee, J.-W., Oh, J.-E., 2010. Occurrence and fate of pharmaceuticals in wastewater treatment plants and rivers in Korea. Environmental Pollution, 158(5), 19381947.

80. Su, C.-C., Bellotindos, L.M., Chang, A.-T., Lu, M.-C., 2013a. Degradation of acetaminophen in an aerated Fenton reactor. Journal of the Taiwan Institute of Chemical Engineers, 44(2), 310-316.

81. Su, C.-C., Cada Jr, C.A., Dalida, M.L.P., Lu, M.-C., 2013b. Effect of UV light on acetaminophen degradation in the electro-Fenton process. Separation and Purification Technology, 120, 43-51.

82. Su, C.-C., Chang, A.-T., Bellotindos, L.M., Lu, M.-C., 2012. Degradation of acetaminophen by Fenton and electro-Fenton processes in aerator reactor. Separation and Purification Technology, 99, 8-13.

83. Sun, Q., Li, M., Ma, C., Chen, X., Xie, X., Yu, C.-P., 2016a. Seasonal and spatial variations of PPCP occurrence, removal and mass loading in three wastewater treatment plants located in different urbanization areas in Xiamen, China. Environmental Pollution, 208, Part B, 371-381.

84. Sun, Q., Li, Y., Li, M., Ashfaq, M., Lv, M., Wang, H., Hu, A., Yu, C.-P., 2016b. PPCPs in Jiulong River estuary (China): Spatiotemporal distributions, fate, and their use as chemical markers of wastewater. Chemosphere, 150, 596-604. 
1014

1015

1016

1017

1018

1019

1020

1021

1022

1023

1024

1025

1026

1027

1028

1029

1030

1031

1032

1033

1034

1035

1036

1037

85. Tambosi, J.L., de Sena, R.F., Favier, M., Gebhardt, W., José, H.J., Schröder, H.F., Moreira, R.d.F.P.M., 2010. Removal of pharmaceutical compounds in membrane bioreactors (MBR) applying submerged membranes. Desalination, 261(1-2), 148-156.

86. Ternes, T.A., 1998. Occurrence of drugs in German sewage treatment plants and rivers. Water Research, 32(11), 3245-3260.

87. Trang, V.N., Dan, N.P., Phuong, L.D., Thanh, B.X., 2014. Pilot study on the removal of TOC, THMs and HAAs in drinking water using ozone/UV - BAC, Desalination and Water Treatment, 52(4-6), 990-998.

88. Trovó, A.G., Pupo Nogueira, R.F., Agüera, A., Fernandez-Alba, A.R., Malato, S., 2012. Paracetamol degradation intermediates and toxicity during photo-Fenton treatment using different iron species. Water Research, 46(16), 5374-5380.

89. Vazquez-Roig, P., Andreu, V., Blasco, C., Picó, Y., 2012. Risk assessment on the presence of pharmaceuticals in sediments, soils and waters of the Pego-Oliva Marshlands (Valencia, eastern Spain). Science of the Total Environment, 440, 24-32.

90. Verlicchi, P., Galletti, A., Petrovic, M., Barceló, D., Al Aukidy, M., Zambello, E., 2013. Removal of selected pharmaceuticals from domestic wastewater in an activated sludge system followed by a horizontal subsurface flow bed - Analysis of their respective contributions. Science of the Total Environment, 454-455, 411-425.

91. Villaroel, E., Silva-Agredo, J., Petrier, C., Taborda, G., Torres-Palma, R.A., 2014. Ultrasonic degradation of acetaminophen in water: Effect of sonochemical parameters and water matrix. Ultrasonics Sonochemistry, 21(5), 1763-1769.

92. Vo, T.D.H., Bui, X.T., Nguyen, D.D., Nguyen, V.T., Ngo, H.H., Guo, W., Nguyen, P.D., Nguyen, C.N., Lin, C., 2018. Wastewater treatment and biomass growth of eight plants for shallow bed wetland roofs, Bioresource Technology, 247, 992-998. 
1038

1039

1040

1041

1042

1043

1044

1045

1046

1047

1048

1049

1050

1051

1052

1053

1054

1055

1056

1057

1058

1059

93. Vo, T.K.Q., Bui, X.T., Chen, S.S., Nguyen, P.D., Cao, N.D.T., Vo, T.D.H., Nguyen, T.T., Nguyen, T.B., 2019. Hospital wastewater treatment by sponge membrane bioreactor coupled with ozonation, Chemosphere, 230, 377-383.

94. Vulliet, E., Cren-Olivé, C., 2011. Screening of pharmaceuticals and hormones at the regional scale, in surface and groundwaters intended to human consumption. Environmental Pollution, 159(10), 2929-2934.

95. Wang, H., Liu, Y., Jiang, J.-Q., 2016a. Reaction kinetics and oxidation product formation in the degradation of acetaminophen by ferrate (VI). Chemosphere, 155, 583-590.

96. Wang, X., Bi, W., Zhai, P., Wang, X., Li, H., Mailhot, G., Dong, W., 2016b. Adsorption and photocatalytic degradation of pharmaceuticals by $\mathrm{BiOCl}_{\mathrm{x}} \mathrm{I}_{\mathrm{y}}$ nanospheres in aqueous solution. Applied Surface Science, 360, Part A, 240-251.

97. Wong, S., Lim, Y., Ngadi, N., Mat, R., Hassan, O., Inuwa, I.M., Mohamed, N.B., Low, J.H., 2018. Removal of acetaminophen by activated carbon synthesized from spent tea leaves: equilibrium, kinetics and thermodynamics studies. Powder Technology, 338, $878-886$.

98. Wu, C., Huang, X., Witter, J.D., Spongberg, A.L., Wang, K., Wang, D., Liu, J., 2014. Occurrence of pharmaceuticals and personal care products and associated environmental risks in the central and lower Yangtze river, China. Ecotoxicology and Environmental Safety, 106, 19-26.

99. Wu, X., Ernst, F., Conkle, J.L., Gan, J., 2013. Comparative uptake and translocation of pharmaceutical and personal care products (PPCPs) by common vegetables. Environment International, 60, 15-22. 
1060

1061

1062

1063

1064

1065

1066

1067

1068

1069

1070

1071

1072

1073

1074

1075

1076

1077

1078

1079

1080

1081

1082

1083

100. Xiao, H., Song, H., Xie, H., Huang, W., Tan, J., Wu, J., 2013. Transformation of acetaminophen using manganese dioxide - mediated oxidative processes: Reaction rates and pathways. Journal of Hazardous materials, 250-251, 138-146.

101. Xie, G., Chang, X., Adhikari, B.R., Thind, S.S., Chen, A., 2016. Photoelectrochemical degradation of acetaminophen and valacyclovir using nanoporous titanium dioxide. Chinese Journal of Catalysis, 37(7), 1062-1069.

102. Xiong, P., Hu, J., 2012. Degradation of acetaminophen by UVA/LED/TiO ${ }_{2}$ process. Separation and Purification Technology, 91, 89-95.

103. Xiong, $\mathrm{P}$., Hu, J., 2017. Decomposition of acetaminophen (Ace) using $\mathrm{TiO}_{2} / \mathrm{UVA} / \mathrm{LED}$ system. Catalyst Today, 282, 48-56.

104. Yang, G.C.C., Huang, S.-C., Wang, C.-L., Jen, Y.-S., 2016. Degradation of phthalate esters and acetaminophen in river sediments using the electrokinetic process integrated with a novel Fenton-like process catalyzed by nanoscale schwertmannite. Chemosphere, $159,282-292$.

105. Yang, L., Yu, L.E., Ray, M.B., 2008. Degradation of paracetamol in aqueous solutions by $\mathrm{TiO}_{2}$ photocatalysis. Water Research, 42(13), 3480-3488.

106. Yanyan, L., Kurniawan, T.A., Ying, Z., Albadarin, A.B., Walker, G., 2017. Enhanced photocatalytic degradation of acetaminophen from wastewater using $\mathrm{WO}_{3} / \mathrm{TiO}_{2} / \mathrm{SiO}_{2}$ composite under UV-VIS irradiation. Journal of Molecular Liquids, 243, 761-770.

107. Yanyan, L., Kurniawan, T.A., Zhu, M., Ouyang, T., Avtar, R., Dzarfan Othman, M.H., Mohammad, B.T., Albadarin, A.B., 2018. Removal of acetaminophen from synthetic wastewater in a fixed-bed column adsorption using low-cost coconut shell waste pretreated with $\mathrm{NaOH}, \mathrm{HNO}_{3}$, ozone, and/or chitosan. Journal of Environmental Management, 226, 365-376. 
1084

1085

1086

1087

1088

1089

1090

1091

1092

1093

1094

1095

1096

1097

1098

1099

1100

1101

1102

1103

1104

1105

108. You, L., Nguyen, V.T., Pal, A., Chen, H., He, Y., Reinhard, M., Gin, K.Y.-H., 2015. Investigation of pharmaceuticals, personal care products and endocrine disrupting chemicals in a tropical urban catchment and the influence of environmental factors. Science of the Total Environment, 536, 955-963.

109. Yu, J.T., Bouwer, E.J., Coelhan, M., 2006. Occurrence and biodegradability studies of selected pharmaceuticals and personal care products in sewage effluent. Agricultural Water Management, 86(1-2), 72-80.

110. Yu, T.-H., Lin, A.Y.-C., Panchangam, S.C., Hong, P.-K.A., Yang, P.-Y., Lin, C.-F., 2011. Biodegradation and bio-sorption of antibiotics and non-steroidal anti-inflammatory drugs using immobilized cell process. Chemosphere, 84(9), 1216-1222.

111. Yu, Y., Wu, L., Chang, A.C., 2013. Seasonal variation of endocrine disrupting compounds, pharmaceuticals and personal care products in wastewater treatment plants. Science of the Total Environment, 442, 310-316.

112. Zhang, H., Cao, B., Liu, W., Lin, K., Feng, J., 2012. Oxidative removal of acetaminophen using zero valent aluminum-acid system: Efficacy, influencing factors, and reaction mechanism. Journal of Environmental Sciences, 24(2), 314-319.

113. Zhang, L., Yin, X., Li, S.F.Y., 2015. Bio-electrochemical degradation of paracetamol in a microbial fuel cell-Fenton system. Chemical Engineering Journal, 276, 185-192.

114. Zhang, S., Zhang, Q., Darisaw, S., Ehie, O., Wang, G., 2007. Simultaneous quantification of polycyclic aromatic hydrocarbons (PAHs), polychlorinated biphenyls (PCBs), and pharmaceuticals and personal care products (PPCPs) in Mississippi river water, in New Orleans, Louisiana, USA. Chemosphere, 66(6), 1057-1069. 
1106 115. Zhang, X., Wu, F., Wu, X., Chen, P., Deng, N., 2008. Photodegradation of 1107 acetaminophen in $\mathrm{TiO}_{2}$ suspended solution. Journal of Hazardous materials, 157(2-3), 300-307. 
1109 Table 1. Classification of ACT levels in WWTPs and surface water of countries

\begin{tabular}{l|l|l|l}
\hline $\begin{array}{l}\text { ACT concentration } \\
\text { range - detection } \\
\text { frequency in WWTPs }\end{array}$ & Countries & $\begin{array}{l}\text { ACT concentration range } \\
\text { compared with } \\
\text { recommended level for } \\
\text { drinking water }(71 \mathrm{ng} / \mathrm{l}) * *\end{array}$ & Countries \\
\hline $\begin{array}{l}\text { Beyond } 100 \mu \mathrm{g} / \mathrm{l}-80- \\
100 \%\end{array}$ & $\begin{array}{l}\text { China, USA, Greece, } \\
\text { UK, Korea, Taiwan }\end{array}$ & $\begin{array}{l}\text { Higher than } \\
\text { recommendation }\end{array}$ & $\begin{array}{l}\text { China, USA, } \\
\text { Taiwan, UK, } \\
\text { Spain, Serbia }\end{array}$ \\
\hline $\begin{array}{l}\text { Below } 100 \mu \mathrm{g} / 1-\text { below } \\
50 \%\end{array}$ & $\begin{array}{l}\text { France, Spain, } \\
\text { Columbia }\end{array}$ & $\begin{array}{l}\text { Lower than } \\
\text { recommendation }\end{array}$ & $\begin{array}{l}\text { France, Spain, } \\
\text { USA, Singapore, } \\
\text { Germany, UK, } \\
\text { Korea }\end{array}$ \\
\hline
\end{tabular}

$1111 * *$ (Vulliet and Cren-Olivé, 2011) 
1113 Table 2. $\mathrm{EC}_{50}$ of aquatic species exposing to ACT

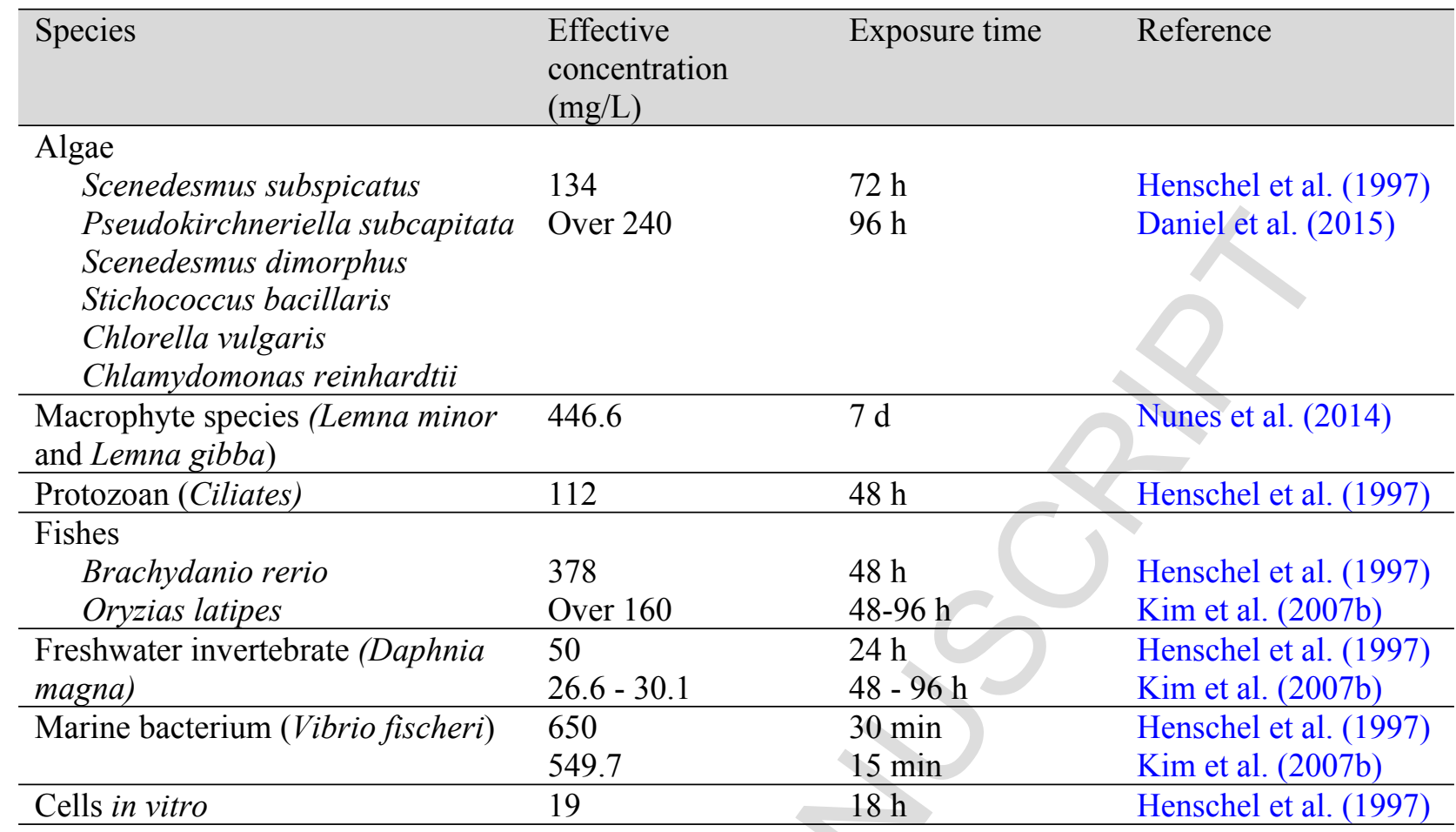


1116 Table 3. Summary of chemical-based Fenton reaction

\begin{tabular}{|c|c|c|c|c|c|c|c|}
\hline Process & {$\left[\mathrm{Fe}^{2+}\right]$} & {$\left[\mathrm{H}_{2} \mathrm{O}_{2}\right]$} & $\mathrm{pH}$ & $\begin{array}{l}\text { Initial ACT } \\
\text { concentratio } \\
\mathrm{n}\end{array}$ & $\begin{array}{l}\text { Removal } \\
\text { efficienc } \\
\mathrm{y}(\%)\end{array}$ & $\begin{array}{l}\text { Retentio } \\
\text { n time }\end{array}$ & References \\
\hline $\begin{array}{l}\text { Photo- } \\
\text { Fenton }\end{array}$ & \multirow{2}{*}{$\begin{array}{l}\mathrm{H}_{2} \mathrm{O}_{2} / \text { Laterit } \\
\text { e iron }= \\
30: 0.75 \\
(w / w)\end{array}$} & \multirow{2}{*}{$\begin{array}{l}30 \mathrm{mg} / \mathrm{L} \\
\mathrm{ACT} / \mathrm{H}_{2} \mathrm{O}_{2} \\
\text { ratio } 1: 3 \\
(w / w)\end{array}$} & \multirow{2}{*}{3} & \multirow{2}{*}{$10 \mathrm{mg} / \mathrm{L}$} & 79 & \multirow{2}{*}{$120 \min$} & \multirow{2}{*}{$\begin{array}{l}\text { Manu and } \\
\text { Mahamoo } \\
\text { d (2011) }\end{array}$} \\
\hline Fenton & & & & & 76 & & \\
\hline $\begin{array}{l}\text { Fenton } \\
\text { with } \\
\text { artificial } \\
\text { ferrous } \\
\text { catalyst } \\
\left(\mathrm{FeSO}_{4}\right)\end{array}$ & \multicolumn{2}{|c|}{$\left[\mathrm{H}_{2} \mathrm{O}_{2}\right]:\left[\mathrm{Fe}^{2+}\right]=60: 1$} & & & 80 & & \multirow{2}{*}{$\begin{array}{l}\text { Basavaraju } \\
\text { et al. } \\
(2011)\end{array}$} \\
\hline $\begin{array}{l}\text { Fenton } \\
\text { with iron } \\
\text { source } \\
\text { from } \\
\text { laterite } \\
\text { soil }\end{array}$ & \multicolumn{2}{|c|}{$\begin{array}{l}{\left[\mathrm{H}_{2} \mathrm{O}_{2}\right]:[\text { Laterite soil }]=} \\
40: 1\end{array}$} & 3 & $10 \mathrm{mg} / \mathrm{L}$ & & 0 min & \\
\hline Fenton & \multirow[b]{2}{*}{$0.1 \mathrm{mM}$} & \multirow{2}{*}{$\begin{array}{l}15 \mathrm{mM} \\
\text { (fixed } \\
\text { value) }\end{array}$} & 2 & \multirow[b]{2}{*}{$5 \mathrm{mM}$} & 99 & \multirow[b]{2}{*}{$120 \mathrm{~min}$} & \multirow[b]{2}{*}{$\begin{array}{l}\text { Su et al. } \\
(2012)\end{array}$} \\
\hline $\begin{array}{l}\text { Electro- } \\
\text { Fenton }\end{array}$ & & & 4 & & 100 & & \\
\hline $\begin{array}{l}\text { Novel } \\
\text { Fenton } \\
\text { aerated } \\
\text { reactor }\end{array}$ & $0.1 \mathrm{mM}$ & $25 \mathrm{mM}$ & 3 & $5 \mathrm{mM}$ & 99 & $40 \mathrm{~min}$ & $\begin{array}{l}\text { Su et al. } \\
\text { (2013a) }\end{array}$ \\
\hline $\begin{array}{l}\text { Fluidized } \\
\text {-bed } \\
\text { Fenton }\end{array}$ & $0.06 \mathrm{mM}^{*}$ & $\begin{array}{l}19.87 \mathrm{mM} \\
*\end{array}$ & 3 & $5 \mathrm{mM}$ & 99.6 & $40 \mathrm{~min}$ & $\begin{array}{l}\text { de Luna et } \\
\text { al. (2013) }\end{array}$ \\
\hline $\begin{array}{l}\text { Bio- } \\
\text { Fenton } \\
\text { (Phyto- } \\
\text { Fenton) }\end{array}$ & n.d & $\begin{array}{l}200-800 \\
\text { nmol g-1 } \\
\text { fresh } \\
\text { weight }\end{array}$ & n. & $1 \& 100 \mathrm{ppb}$ & $55-99.8 \%$ & $5 \mathrm{~d}$ & $\begin{array}{l}\text { Phong et } \\
\text { al. (2016) }\end{array}$ \\
\hline
\end{tabular}

Remark: n.d: no data; *treated solution 
1119 Table 4. Summary of photo-based and electro-based Fenton process

\begin{tabular}{|c|c|c|c|c|c|c|c|}
\hline Process & Light source & $\begin{array}{l}\text { Catalyst } \\
\text { dose }\end{array}$ & $\mathrm{pH}$ & $\begin{array}{l}\text { Initial ACT } \\
\text { concentration }\end{array}$ & $\begin{array}{l}\text { Removal } \\
\text { efficienc } \\
\mathrm{y}(\%)\end{array}$ & Retention time & References \\
\hline $\begin{array}{l}\text { Suspended } \\
\mathrm{TiO}_{2}\end{array}$ & $\begin{array}{l}\text { Metal halide } \\
\text { lamp } 250 \\
\mathrm{~W}, \geq \\
365 \mathrm{~nm})\end{array}$ & $1.0 \mathrm{~g} / 1$ & 3.5 & $100 \mu \mathrm{mol} / 1$ & 95 & $100 \min$ & $\begin{array}{l}\text { Zhang et } \\
\text { al. (2008) }\end{array}$ \\
\hline \multirow{2}{*}{$\begin{array}{l}\text { Suspended } \\
\text { non-porous } \\
\mathrm{TiO}_{2}\end{array}$} & $\begin{array}{l}\text { UVA ( } 8 \mathrm{~W}, \\
365 \mathrm{~nm})\end{array}$ & \multirow{2}{*}{$0.4 \mathrm{~g} / 1$} & \multirow{2}{*}{9.5} & $2 \mathrm{mM}$ & 50 & $300 \mathrm{~min}$ & \multirow{2}{*}{$\begin{array}{l}\text { Yang et al. } \\
(2008)\end{array}$} \\
\hline & $\begin{array}{l}\text { UVC (15W, } \\
254 \mathrm{~nm})\end{array}$ & & & $4 \mathrm{mM}$ & 95 & $80 \mathrm{~min}$ & \\
\hline $\begin{array}{l}\mathrm{TiO}_{2} / \\
\text { reticulated } \\
\text { vitreous carbon } \\
\text { assisted UV }\end{array}$ & $\begin{array}{l}\text { UV mercury } \\
\text { vapor lamp } \\
(350 \mathrm{~nm} \\
\text { peak })\end{array}$ & $\begin{array}{l}1 \mathrm{~g} \\
\text { binding } \\
\text { on } \\
\text { reticulat } \\
\text { ed } \\
\text { vitreous } \\
\text { carbon } \\
\text { anode } \\
\end{array}$ & n.d & $96 \mathrm{mg} / \mathrm{l}$ & & $60 \mathrm{~min}$ & $\begin{array}{l}\text { Arredondo } \\
\text { Valdez et } \\
\text { al. (2012) }\end{array}$ \\
\hline $\begin{array}{l}\text { Non-porous } \\
\mathrm{TiO}_{2}-\mathrm{P} 25\end{array}$ & $\begin{array}{l}\text { UVA/LED } \\
(365 \mathrm{~nm}) \\
1-3 \mathrm{~mW} / \mathrm{cm}^{2}\end{array}$ & $0.2 \mathrm{mg} / \mathrm{l}$ & 5.6 & $200 \mathrm{ppb}$ & 100 & $15 \mathrm{~min}$ & $\begin{array}{l}\text { Xiong and } \\
\mathrm{Hu}(2012)\end{array}$ \\
\hline $\begin{array}{l}\text { ZSM-5 } \\
\text { supported } \mathrm{TiO}_{2}\end{array}$ & $\begin{array}{l}\text { UV lamp } \\
(254 \mathrm{~nm}) \\
0.97 \\
\mathrm{~mW} / \mathrm{cm}^{2}\end{array}$ & $\begin{array}{l}\mathrm{TiO}_{2}: \\
\mathrm{ZSM}-5 \\
\text { as } 40 \\
\mathrm{wt} \% \\
\end{array}$ & 6.8 & $15 \mathrm{mg} / \mathrm{l}$ & 96.6 & $180 \mathrm{~min}$ & $\begin{array}{l}\text { Chang et } \\
\text { al. (2015) }\end{array}$ \\
\hline $\begin{array}{l}\text { Planar and } \\
\text { porous Ti/ } \\
\text { BDD } \\
\text { electrodes }\end{array}$ & None & - & & $100 \mathrm{mg} / \mathrm{l}$ & 100 & $20-25 \mathrm{~h}$ & $\begin{array}{l}\text { He et al. } \\
(2015)\end{array}$ \\
\hline $\begin{array}{l}\mathrm{US} / \text { Fenton/TiO } \\
{ }_{2} \mathrm{NT}\end{array}$ & None & $\begin{array}{l}\mathrm{TiO}_{2} \mathrm{NT} \\
\text { as anode } \\
\mathrm{US} 1000 \\
\mathrm{kHz}\end{array}$ & 3 & $3 \mu \mathrm{M}$ & 85.3 & $30 \mathrm{~min}$ & $\begin{array}{l}\text { Im et al. } \\
\text { (2015) }\end{array}$ \\
\hline \multirow[t]{2}{*}{$\begin{array}{l}\text { Non-porous } \\
\mathrm{TiO}_{2}-\mathrm{P} 25\end{array}$} & \multirow{2}{*}{$\begin{array}{l}\text { UVA/LED } \\
(365 \mathrm{~nm}) \\
5 \mathrm{~mW} / \mathrm{cm}^{2}\end{array}$} & $10 \mathrm{ppm}$ & \multirow[t]{2}{*}{5.6} & $200 \mathrm{ppb}$ & - & $\begin{array}{l}20 \mathrm{~min} \text { as } 20 \% \\
\text { time of periodic } \\
\text { illumination }\end{array}$ & \multirow[t]{2}{*}{$\begin{array}{l}\text { Xiong and } \\
\mathrm{Hu}(2016)\end{array}$} \\
\hline & & $100 \mathrm{ppm}$ & & $20 \mathrm{ppm}$ & $70-100^{*}$ & $60 \mathrm{~min}$ & \\
\hline $\begin{array}{l}\text { Carbon self- } \\
\text { doped (C- } \\
\text { doped) } \mathrm{TiO}_{2}\end{array}$ & $\begin{array}{l}\text { LED } \\
(440-490 \\
\mathrm{nm})\end{array}$ & $1.0 \mathrm{~g} / 1$ & 6.9 & $0.1 \mathrm{mM}$ & 94 & $\begin{array}{l}30 \text { min for } \\
\text { adsorption } \\
9 \mathrm{~h} \text { for photo- } \\
\text { degradation }\end{array}$ & $\begin{array}{l}\text { de Luna et } \\
\text { al. (2016) }\end{array}$ \\
\hline $\begin{array}{l}\text { Nano-porous } \\
\mathrm{TiO}_{2}\end{array}$ & $\begin{array}{l}\text { UV visible } \\
\text { lamp } \\
(365,405 \\
\text { and } 435 \mathrm{~nm}) \\
130 \\
\mathrm{~mW} / \mathrm{cm}^{2}\end{array}$ & - & - & $40 \mathrm{ppm}$ & 86.96 & $60 \mathrm{~min}$ & $\begin{array}{l}\text { Xie et al. } \\
\text { (2016) }\end{array}$ \\
\hline $\begin{array}{l}\text { Hollow core- } \\
\text { shell } \\
\text { mesoporous }\end{array}$ & $\begin{array}{l}\text { UV mercury } \\
\text { vapor lamp }\end{array}$ & $0.1 \mathrm{~g} / 1$ & - & $50 \mathrm{mg} / 1$ & 94 & $60 \mathrm{~min}$ & $\begin{array}{l}\text { Lin et al. } \\
\text { (2016a) }\end{array}$ \\
\hline
\end{tabular}




\begin{tabular}{|c|c|c|c|c|c|c|c|}
\hline $\begin{array}{l}\mathrm{TiO}_{2} \\
\text { microspheres }\end{array}$ & $\begin{array}{l}(500 \mathrm{~W}, 245 \\
\mathrm{nm})\end{array}$ & & & & & & \\
\hline $\begin{array}{l}\mathrm{TiO}_{2} \text { doping } \\
\mathrm{K}_{2} \mathrm{~S}_{2} \mathrm{O}_{8}\end{array}$ & $\begin{array}{l}\text { LED (450 } \\
\mathrm{nm} \text { peak) } \\
16.85 \\
\mathrm{~mW} / \mathrm{cm}^{2}\end{array}$ & $1 \mathrm{~g} / 1$ & 9 & $0.1 \mathrm{mM}$ & 100 & $9 \mathrm{~h}$ & $\begin{array}{l}\text { Lin et al. } \\
\text { (2016b) }\end{array}$ \\
\hline $\begin{array}{l}\text { Fenton like } \\
\text { with nano- } \\
\text { Schwertmannit } \\
\text { e catalyst, } \\
\text { assisted EK }\end{array}$ & $\begin{array}{l}5.631 \times 10^{-6} \\
\text { to } 1.126 \times \\
10^{-5} \mathrm{~mol} \mathrm{~g}^{-1}\end{array}$ & $\begin{array}{l}1.126 \times \\
10^{-4} \text { to } \\
2.253 \times \\
10^{-4} \\
\mathrm{~mol} / \mathrm{g}\end{array}$ & $\begin{array}{l}\text { Ano } \\
\text { de } \\
\text { as } 2 \\
\text { Cat } \\
\text { hod } \\
\text { e as } \\
12 \\
\text { Sed } \\
\text { ime } \\
\text { nt } \\
\text { as } \\
6- \\
12\end{array}$ & $\begin{array}{l}500 \mu \mathrm{g} / \mathrm{kg} \\
\text { sediment }\end{array}$ & 100 & 14 or $28 \mathrm{~d}$ & $\begin{array}{l}\text { Yang et al. } \\
(2016)\end{array}$ \\
\hline $\mathrm{WO}_{3} / \mathrm{TiO}_{2} / \mathrm{SiO}_{2}$ & $\begin{array}{l}\text { Full } \\
\text { waveband } \\
\text { xenon lamp } \\
\text { coupled } \\
\text { with a cutoff } \\
\text { filter (500 } \\
W, 800 \mathrm{~nm} \\
>\lambda>200 \\
\mathrm{~nm})\end{array}$ & $1.5 \mathrm{~g} / 1$ & 9 & $5 \mathrm{mg} / 1$ & 95 & $4 \mathrm{~h}$ & $\begin{array}{l}\text { Yanyan et } \\
\text { al. (2017) }\end{array}$ \\
\hline $\mathrm{BaTiO}_{3} / \mathrm{TiO}_{2}$ & $\begin{array}{l}\text { Xenon lamp } \\
(500 \mathrm{~W}, 200 \\
\mathrm{nm}<\lambda< \\
800 \mathrm{~nm})\end{array}$ & $1 \mathrm{~g} / 1$ & & $5 \mathrm{mg} / \mathrm{l}$ & 95 & $4 \mathrm{~h}$ & $\begin{array}{l}\text { Kurniawan } \\
\text { et al. } \\
(2018)\end{array}$ \\
\hline
\end{tabular}


Table 5. Main metabolites of ACT degradation

\begin{tabular}{|c|c|c|c|}
\hline Applied technology & Driving agent & Main by-products & Reference \\
\hline $\begin{array}{l}\text { Chemical-based } \\
\text { Fenton }\end{array}$ & $\cdot \mathrm{OH}$ & $\begin{array}{l}\text { Hydroquinone, amide, ammonia, } \\
\text { formic acid and 1,2-pentanediol }\end{array}$ & de Luna et al. (2013) \\
\hline Photo-based Fenton & ${ }^{\circ} \mathrm{OH}, \mathrm{v}$ & $\begin{array}{l}\text { Ring-opening products, } \mathrm{CO}_{2} \\
\text { ammonium, nitrates ions }\end{array}$ & Yang et al. (2008) \\
\hline Photo-based-Fenton & $\cdot \mathrm{OH}, \mathrm{v}$ & $\begin{array}{l}\text { Hydroxylated intermediates, } \\
\text { acetamide }\end{array}$ & Trovó et al. (2012) \\
\hline Photo-based Fenton & $\cdot \mathrm{OH}, \mathrm{v}$ & $\begin{array}{l}\text { Hydroquinone and 2-hydroxy-4- } \\
\text { ( } N \text {-acetyl)-aminophenol }\end{array}$ & $\begin{array}{l}\text { Andreozzi et al. } \\
(2003)\end{array}$ \\
\hline Photo-based Fenton & $v, \mathrm{CO}_{3}^{2-}$ & $\begin{array}{l}\text { Hydroxylated derivatives, ring- } \\
\text { opening compounds, dimers and } \\
\text { trimers }\end{array}$ & $\begin{array}{l}\text { De Laurentiis et al. } \\
(2014)\end{array}$ \\
\hline Photo-based Fenton & $\cdot \mathrm{OH}, \mathrm{v}$ & $\begin{array}{l}\text { Hydroquinone, } 1,4- \\
\text { benzoquinone, } 1-(2- \\
\text { hydroxyphenyl-5-amino }) \\
\text { ethanone and 1-(2-amino-5- } \\
\text { hydroxyphenyl) ethanone }\end{array}$ & Chang et al. (2015) \\
\hline $\begin{array}{l}\text { Photo and electro- } \\
\text { based Fenton }\end{array}$ & $\cdot \mathrm{OH}, \mathrm{v}$ & $\begin{array}{l}\text { Benzoquinone, hydroquinone } \\
\text { and carboxylic acid }\end{array}$ & $\begin{array}{l}\text { Arredondo Valdez et } \\
\text { al. (2012) }\end{array}$ \\
\hline Electro-based Fenton & $\cdot \mathrm{OH}$ & $\begin{array}{l}\text { Hydroquinone, amide, 1-penten- } \\
\text { 3-ol,2-methyl,4-heptanol and } \\
\text { 2,3-butadiol }\end{array}$ & de Luna et al. (2012) \\
\hline Chlorination process & $\mathrm{ClO}^{-}$ & $\begin{array}{l}\text { 1,4-benzoquinone, N-acetyl-p- } \\
\text { benzoquinone amine, chloro-4- } \\
\text { acetamidophenol and dichloro- } \\
\text { 4-acetamidophenol }\end{array}$ & $\begin{array}{l}\text { Bedner and } \\
\text { MacCrehan (2006) }\end{array}$ \\
\hline Membrane (MBR) & - & $\begin{array}{l}\text { Acetaminophen-O-sulphate, } \\
\text { acetaminophen-glutathione }\end{array}$ & Tambosi et al. (2010) \\
\hline Others & $\cdot \mathrm{OH}$ & $\begin{array}{l}\text { Hydroquinone, formic acid, } \\
\text { ammonia and } \mathrm{CO}_{2}\end{array}$ & Zhang et al. (2012) \\
\hline Others & Ferrate (VI) & $\begin{array}{l}\text { Hydroxylated derivatives, } \\
\text { maleic acid, oxalic acid and } \\
\text { formic acid }\end{array}$ & Wang et al. (2016a) \\
\hline Others & $\mathrm{MnO}_{2}$ & Dimers and trimers & Xiao et al. (2013) \\
\hline
\end{tabular}


1124 List of Figures

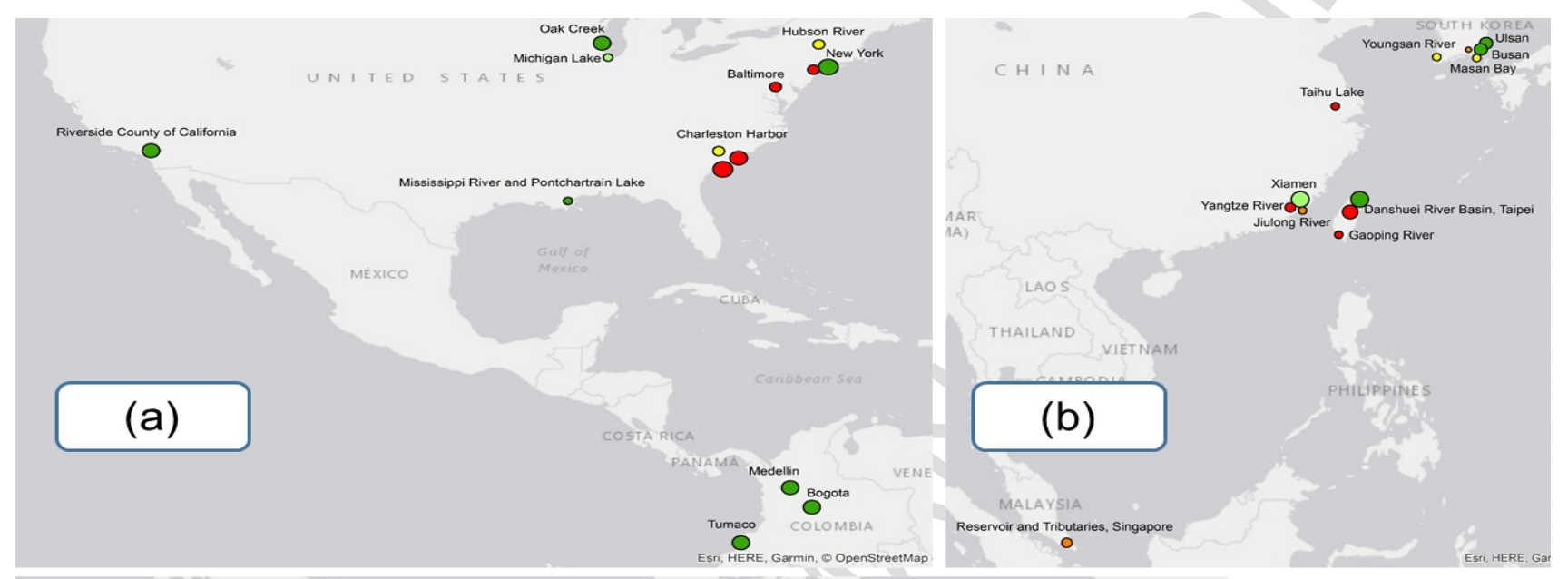

Fig. 1. Occurrence of ACT in various environments in (a) America, (b) Asia and (c) Europe 
1127

1128

1129

1130

1131

1132

1133

1134

1135

1136

1137

1138

1139

1140

1141

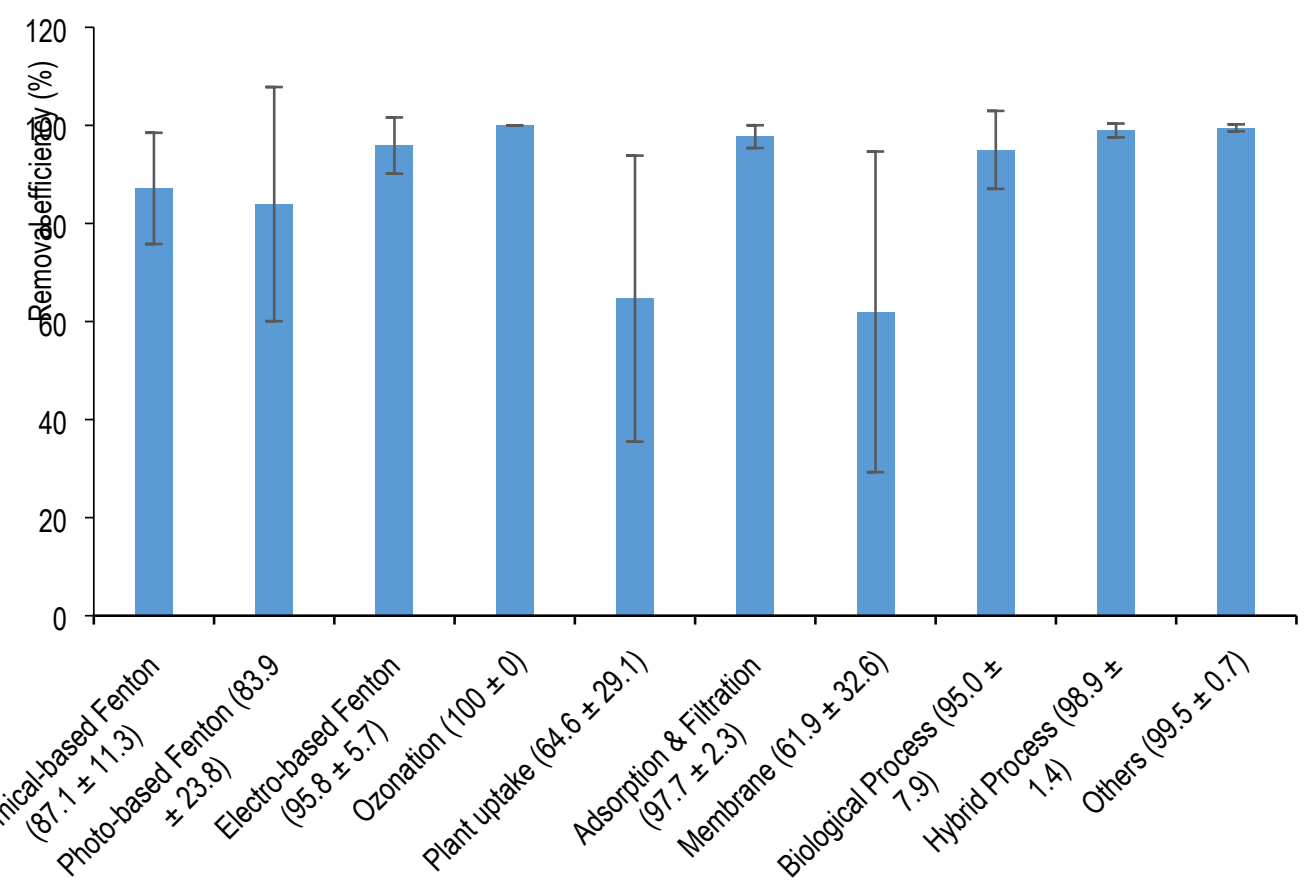

Fig. 2. Comparison of ACT removal efficiency by technologies. X-axis exhibits the technologies and their mean ACT removal efficiencies and standard deviations (in the brackets). Error bars represent the standard deviations of the data.

(Amouzgar et al., 2017; Arredondo Valdez et al., 2012; Ba et al., 2014; Behera et al., 2011; Boleda et al., 2011; Chang et al., 2015; Chang et al., 2014; de Luna et al., 2013; de Luna et al., 2016; Gallardo-Altamirano et al., 2018; Gros et al., 2010; He et al., 2015; Huber et al., 2009; Im et al., 2015; Kasprzyk-Hordern et al., 2009; Kim and Tanaka, 2009; Kurniawan et al., 2018; Lin et al., 2016a; Lin et al., 2016b; Lutpi et al., 2015; Manu and Mahamood, 2011; Manu et al., 2011; Mashayekh-Salehi et al., 2017; Narumiya et al., 2013; Nguyen et al., 2013; Phong et al., 2016; Quiñones et al., 2015; Radjenović et al., 2008; Ranieri et al., 2011; Rosal et al., 2010; Su et al., 2013a; Su et al., 2013b; Su et al., 2012; Verlicchi et al., 2013; Villaroel et al., 2014; Wong et al., 2018; Xie et al., 2016; Xiong and Hu, 2017; Yang et al., 2016; Yang et al., 2008; Yanyan et al., 2017; Yanyan et al., 2018; Yu et al., 2006; Yu et al., 2011; Zhang et al., 2012; Zhang et al., 2008) 


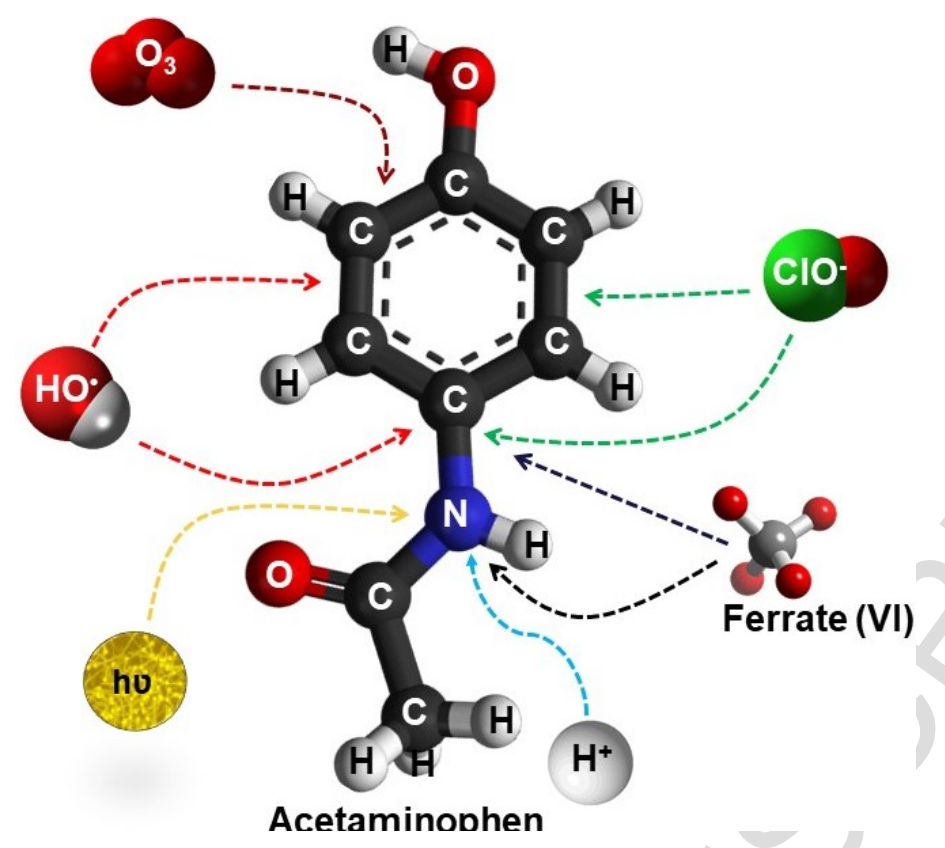

1144

Fig. 3. Oxidative agents encounter on bonding of ACT molecule

1145

1146 

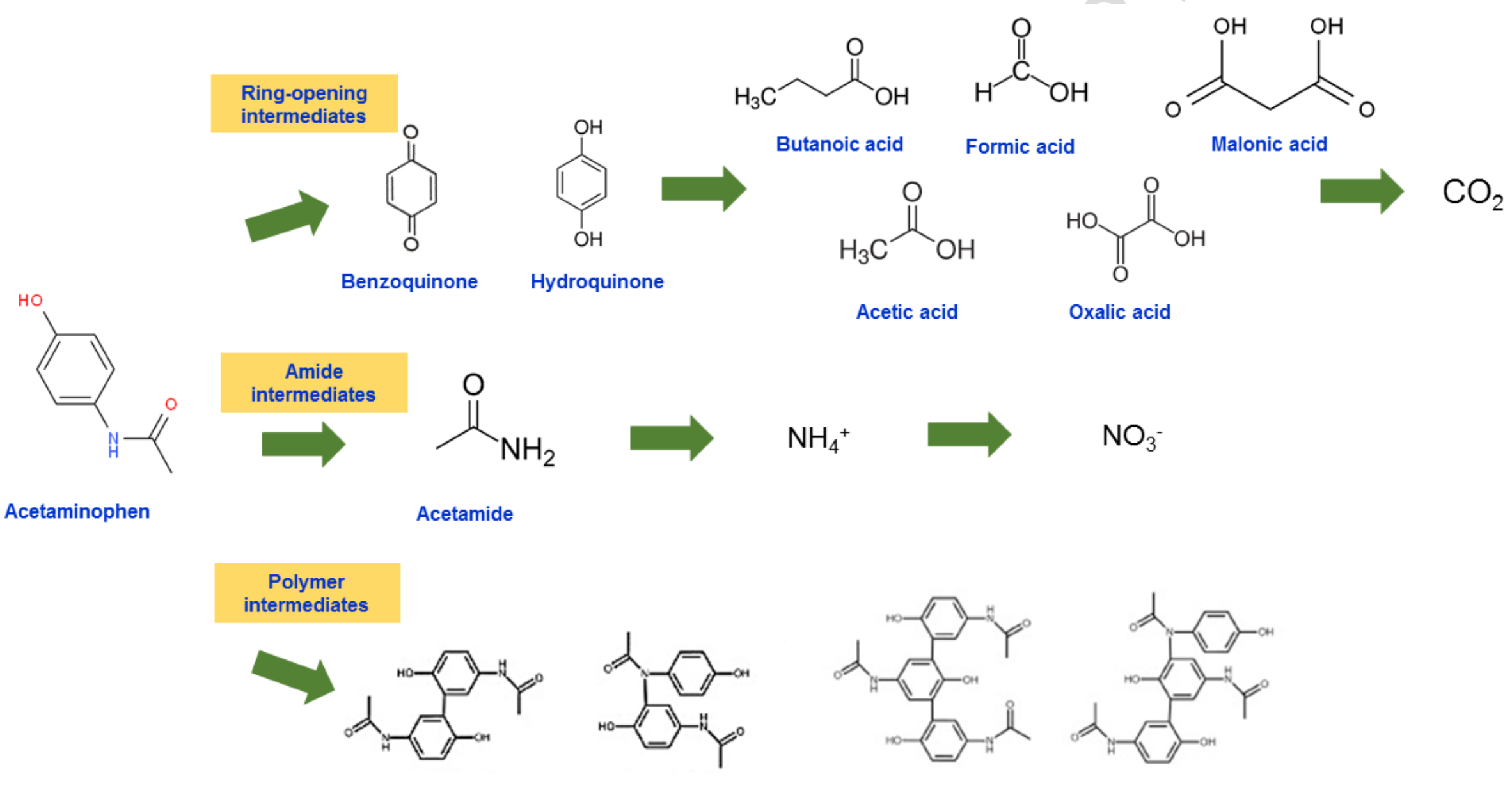

$\mathrm{NH}_{4}^{+} \longrightarrow \mathrm{NO}_{3}{ }^{-}$

Acetaminophen

Acetamide

$$
\text { Polymer }
$$
intermediates
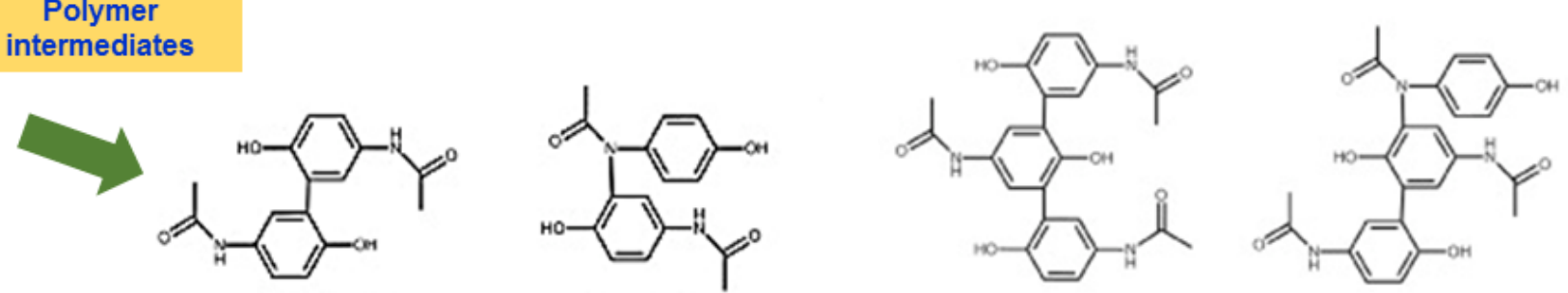

$M_{W}=\mathbf{3 0 0}$

$M_{W}=300$

Dimers

$M_{W}=449$

$M_{W}=449$ 


\section{Highlights}

- China and the USA showed the highest acetaminophen (ACT) concentration

- Advanced oxidation processes (AOPs) removed ACT to the ppt level

- More than 20 by-products and intermediates of ACT were detected

- Treated wastewater was not totally free from the toxic effects due to ACT metabolites 
